\title{
PROTECTING OURSELVES FROM OURSELVES: AN ETHICAL ANALYSIS OF SUICIDE AND SUICIDE INTERVENTION
}

\author{
Paul Nicholas Homer \\ Mineola, New York
}

B.A., Adelphi University, 1981

A Thesis Presented to the Graduate Faculty of the University of Virginia in Candidacy for the Degree of Master of Arts

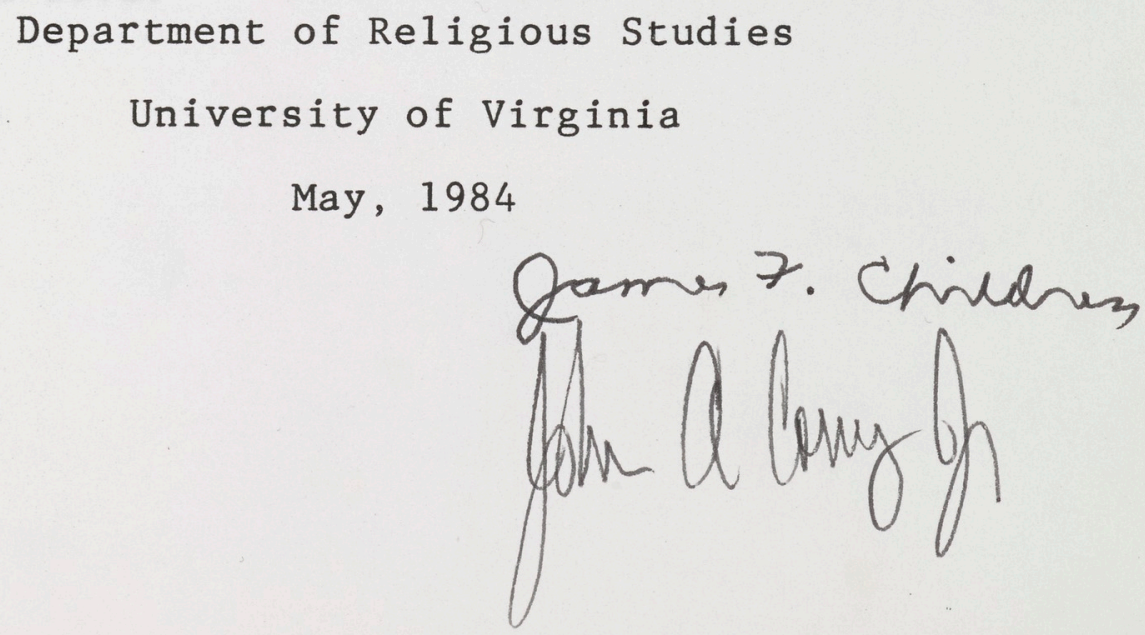





\section{ACKNOWLEDGMENTS}

I would like to take this opportunity to express my gratitude to several people who seem to possess an ingenuous ability to balance kindness and respect and whose support and encouragement have made this work possible: My advisor, Professor James Childress of the Department of Religious Studies, University of Virginia; Steven Dalle-Mura and David Bosco, graduate students in Religious Studies at the University of Virginia, whose encouragement and criticisms were always helpful and whose friendship provided me with much support; and Professor Stephen Greenfield and Professor James Fennelly of the Department of Religious Studies, Adelphi University. Special thanks to my friends and family, especially Mom, Dad, Christopher, and Kelly Anne to whom I cannot begin to express my thanks. I wish to dedicate this work to my grandparents--Myldred, August, Rita, and Nicholas--who have taught me much about life and love. 


\section{TABLE OF CONTENTS}

INTRODUCTION: The Tragic Figures of Suicide

CHAPTER I. The Definition of Suicide

CHAPTER II. The Contemporary Debate: Some New Variations on Some 0ld Themes

CHAPTER III. Suicide Intervention: A Study in Paternalism

CONCLUSION: The Challenge of Suicide 
The moral life is fundamentally the life of vision, for the task is to see accurately the nature of the world, self, and others without illusion.

Stanley Hauerwas, Vision and Virtue

What one sees and does not see is related to where one stands.

James M. Gustafson, Ethics from a Theocentric Perspective

Suicides were the aristocrats of death--God's graduate students, acting out their theses to prove how limited were the alternatives. He had allowed Himself and His creatures. Their act was, at its best, superb literary criticism.

Daniel Stern, The Suicide Academy

We are..horrified at the very thought of suicide; by it man sinks lower than the beasts; we look upon the suicide as carrion, whilst our sympathy goes forth to the victim of fate.

Immanuel Kant, Lectures on Ethics 


\section{INTRODUCTION: The Tragic Figures of Suicide}

Suicide is a phenomenon that has existed throughout the ages and across cultures. While the prominence of many moral issues tends to wax and wane in the face of social and technological changes, suicide seems to transcend such vicissitudes.

History and literature are replete with tragic figures who have chosen to end their own lives: Jocasta, Socrates, Cato the Younger, Antony and Cleopatra, Romeo and Juliet, and more recently, Sylvia Plath, Henry Pitney Van Dusen and his wife, and Arthur Koestler and his wife. The means employed, or what some have called the "art of suicide," have become slightly more sophisticated, but many of the causes, values, and underlying questions connected with the issue remain the same.

Recent studies have greatly contributed to our understanding of suicide. These studies seem to indicate, for example, that a suicide is comprised of a complex matrix of variables and that the decision to attempt suicide is not a single choice, but is often the culmination of a long series of choices. While most of the research in the fields of medicine, psychology, and sociology having to do with suicide has been conducted within the last one hundred years, suicide has always been an object of great concern to philosophers and theologians. 
There is but one truly serious philosophical problem and that is suicide. Judging whether life is or is not worth living amounts to answering the fundamental question of philosophy. All the rest--whether or not the world has three dimensions, whether the mind has nine or twelve categories--comes afterwards.

\section{Albert Camus, The Myth of Sisyphus}

Suicide has fascinated and frustrated philosophers because "it raises the marital disputes of order and freedom, effort and indulgence, holiness and happiness, authority and conscience, which have vexed philosophy for as long as these problems have been thought of, and are unable to achieve any permanent solution."1 This is not to say that a solution has never been proposed or adopted. Suicide has long been condemned by traditional Church teaching and, until recently, it was prohibited in many legal jurisdictions. St. Augustine described suicide as a "detestable and damnable wickedness," and since then, suicide has, for the most part, been seen as indicating a "dry rot of the soul, a perverse and pernicious setting-at-nought of all human values, and a cowardly flight from the duties and burdens to which all human flesh is heir." 2

But this view has been challenged by others. A1though few would support unconditionally the practice of suicide, many have held that under certain conditions, suicide may be a legitimate, if not appropriate, option. 
vii

Greek philosophers recognized some exceptions to a general prohibition of suicide. Some Stoic philosophers even held that suicide may serve as the ultimate expression of personal courage and wisdom. Suicide could be interpreted, according to this school of thought, as an affirmation of one's capacity for compassion and freedom.

While Western Culture has never fully embraced the Stoic view, it is slowly moving away from the belief that suicide is an abomination. This change has not resulted from some great philosophical enlightenment as much as from a real and tragic situation that is occuring with greater regularity. The current state of biomedical technology has made it possible for "ill and seriously injured persons to prolong their lives beyond a point at which, in former times, they would have died. Many of those patients are seriously ill and in considerable agony." 3 suicide may present these people with a means of avoiding the pains and indignities to which this technology presently subjects them. The mere knowledge that suicide is an option may provide a great source of relief and comfort to these people and others who suffer.

The thought of suicide is a great consolation: by means of it one gets successfully through many a bad night.

Nietzsche, Beyond Good and Evil 
viii

We are in the power of no calamity while death is in our own.

Sir Thomas Browne, Religio Medici

Unfortunately, changes in the law have not come about as quickly as advances in biomedical technology. Although suicide has been decriminalized in the United States, the legislatures and courts have been hesitant to promulgate one's rights in this area. This hesitancy on the part of society and its lawmakers is probably due to the influence of its religious legacy coupled with a moral and pragmatic concern for the consequences of such an action.

Studies have found that no significant correlation exists between the legal status of suicide and suicide rates. Fluctuations in the suicide rate are more likely due to other variables. These suicide rates are the other tragic figures of suicide.

In the United States, there are nearly 30,000 reported cases of suicide per year. An individual is three times as likely to die from suicide as from homicide. Suicide is currently ranked as the ninth leading cause of death, accounting for $1.4 \%$ of total deaths. 4 More recent studies indicate that this rate is higher for certain populations. For example, among teenagers, ages 15-19, suicide ranks as the second leading cause of death--behind accidents. 
These figures are disturbing and alarming. Though there may be little agreement on the inherent morality of suicide, there is one point that few will dispute: Suicide is a moral issue. The fact that it involves death, an irreversible harm, makes it a moral issue of particular gravity.

If suicide is allowed then everything is allowed. If anything is not allowed then suicide is not allowed. This throws a light on the nature of ethics, for suicide is, so to speak, the elementary sin.

Ludwig Wittgenstein, Notebooks 1914-1919

In this thesis, I do not propose to offer a definitive solution to the problem of suicide. I intend, instead, to develop a defensible position based on an examination and assessment of the major moral principles which are relevant to a discussion of the moral status of suicide.

In the first chapter, I indicate the difficulties involved in formulating a definition of suicide. A working definition is stipulated at the end of this chapter.

In chapter II, I begin by describing some of the factors that must be taken into account in any discussion of the morality of suicide. It is in this chapter that an analysis of the pertinent moral principles takes place. An argument will be put forward for a moral 
right to suicide.

While the role of the agent is the primary moral issue, an important secondary moral issue is examined in chapter III: the role of the bystander. How should we respond to the individual who is considering or attempting suicide? What values are expressed by the various responses that we can make to that individual?

In the final section, some concluding remarks will be made concerning the challenge that suicide poses to us as individuals and as a society.

Throughout the thesis, I have interspersed quotations from philosophy, literature, and poetry. Writers from many disciplines have contributed to our understanding and appreciation of the multifarious dimensions of the problem of suicide.

It is my conviction that a reader can learn more about human agency from great novels than he or she can from philosophical treatises or scientific accounts of the subject. Ethics from a Theocentric Perspective

Poetry and literature do not just bolster our moral intentions; they affect how we perceive the world and hence what the moral life is all about. For poetry does not just describe the known; it reveals dimensions of the unknown that make the known seem unfamiliar.

Stanley Hauerwas, Vision and Virtue 
1 Glanville Williams, The Sanctity of Life and $\frac{\text { the Criminal Law }}{\text { p.248. (New York: Alfred A. Knopf, 1957), }}$

2 Sidney Hook, "The Ethics of Suicide," in Beneficent Euthanasia, ed. Marvin Kohl (Buffalo, N.Y.: $\frac{\text { Pro- }}{\text { Prol }}$ metheus Books, 1975), p.58.

3 Tom Beauchamp, "Suicide," in Matters of Life $\frac{\text { and Death }}{\text { P.67. }}$ ed. Tom Regan (New York: Random House, 1980),

4 United States Department of Health and Human Services, Public Health Service, National Center for Health Statistics, Vital Statistics of the United States 1978: Volume II--Mortality, tables 1-5, 1-6, and 1-9. 


\section{CHAPTER 1: The Definition of Suicide}

Everywhere there were people living out their daily lives using aspects of suicide against themselves. They did not even have the authenticity of the final act to speak for them. Suicide is, in short, the one continuous, every-day, ever-present problem of living. It is a question of degree. I'd seen them all in varying stages of development and despair. The failed lawyer, the cynical doctor, the depressed housewife, the angry teen-ager... all of mankind engaged in the massive conspiracy against their own lives that is their daily activity. The meaning of suicide, the true meaning, had yet to be defined, had yet to be created in the broad dimensions it deserved.

Daniel Stern, The Suicide Academy

The discussion of the morality of suicide raises many difficult questions. Perhaps the most difficult of these questions to answer is the first one: What is suicide? Many arguments on both sides of the issue proceed on the assumption that it is not necessary to provide a definition of suicide. Everybody knows what suicide is, just as everybody knows what murder is. This is the first fallacy of suicide. Émile Durkheim begins his classic work, Suicide: A Study in Sociology, with this caveat:

Since the word 'suicide' recurs constantly in the course of conversation, it might be thought that its sense is universally known and that definition is superfluous. Actually, the words of everyday language, like the concepts they express, are always susceptible of more than one meaning, and the scholar employing them in their accepted use without further definition would risk misunderstanding. 1 
If all who are involved in the debate were asked to articulate their definitions, they might be suprised at the heterogeneity of their responses. In many instances, those who call for an absolute proscription of suicide are working with a different understanding of the act than are those who would want to recognize a right to suicide. I do not wish, however, to imply that differences in normative claims will disappear if a single definition were to be adopted. The problem of suicide is far from being simply one of definition.

The language of suicide has a history nearly as interesting as that of the act itself. ${ }^{2}$ The term 'suicide,' for instance, does not antedate the seventeenth century. Prior to then, few languages had a term specifically referring to suicide. The concept was described in various ways so as to emphasize a particular quality of the act. Suicide was usually described as either a type of dying or a type of killing. "Latin mors voluntaria stresses the voluntary nature of such dying. English 'suicide,' 'self-killing,' the fact that oneself is the object." 3 The Germans have two words that have been used to describe suicide. The term Selbstmord is the exact equivalent of 'self-murder.' Freitod is translated as 'free-death.' The latter term was not introduced until this century and was applied to deaths that were considered too noble to be described 
as Selbstmord.

The main difficulty in attempting to formulate an adequate definition of suicide stems from the fact that the term has been imbued with more than just a descriptive function. 'Suicide' is a value-laden and affect-laden term that tends to educe strong convictions and feelings. As Tom Beauchamp and James Childress note, "Terms in their ordinary meaning often contain evaluative accretions from social attitudes that render them difficult to analyze. The meaning...located for 'suicide' appears to be a premier example." 4

The definition and application of the term has been greatly affected by the legal, moral, and religious values of society. The application of the label 'suicide' to an act has depended not only on some empirical criteria, but also on whether the act was deemed to be praiseworthy or contemptible. For centuries, suicide would bring ignominy and damnation upon the agent and would result in his or her estate being forfeited over to the state. It would also bring dishonor to the agent's family. If the act was judged to be praiseworthy, the term 'suicide' was not applied. Joseph Margolis, an American philosopher, has noted:

The very category of suicide interprets, in terms of some selective doctrine, the intentions and conduct of agents said to have taken or to have attempted to take their own lives and to provide for the appraisal of those 
actions: there is no neutral concept of suicide, and what is allowed or disallowed as a fair specimen reflects at least conditions that alternatively favored creeds would have to meet in order to be minimally coherent, if it does not already exhibit their actual preferences. 5

Catholic teaching, for example, defines suicide as an "unlawful act, positive or negative, by which one directly causes his own death."6 Catholic teaching does recognize as lawful some cases in which one may be said to have caused his or her own death. Such cases, however, will not be described as suicides in this tradition. For the act to qualify as a suicide according to Catholic teaching, it must also be subject to a moral assessment in which it is found to be unlawful. The point is that cases which fall outside the Catholic definition of suicide may be justified cases of suicide according to another definition.

In this chapter, I wish to distinguish the discussion of the definition of suicide from a discussion of its possible moral justification and then stipulate a nonmoral definition of suicide that attempts to capture the essential elements of our ordinary understanding of the term.

In order to develop such a definition, it is necessary to make two adjustments in the language often associated with suicide. The expression "to commit suicide" is purposely avoided, because it implies that 
something wrong or reprehensible is done, i.e., a judgment has been made. In addition, the noun 'suicide,' used to indicate the one who has taken his or her life, is rejected, "recognizing that a person who kills herself (or himself) is also a person who does many other things and that a person cannot be confined to a single act." 7 What, then, is suicide?

Case 1-1: Alice, a college senior, after receiving a failing grade for a course, feels that life is no longer worth living. She decides to end her life and that night jumps from her dormitory window to her death.

There would appear to be little doubt that Alice's death was a suicide. If there is such a thing as a clear case of suicide, this is it. But what in particular about this act makes it a suicide? What distinguishes it from other forms of death?

The Oxford English Dictionary defines suicide as an "act of taking one's life, self-murder."8 Because murder involves a normative claim in addition to a descriptive one, I wish to concentrate solely on the first part of the definition: an "act of taking one's life." Fundamental to any understanding of suicide is the notion of a reflexive act, i.e., self-agency. The fact that the one who is killed and the one who takes the life are the same person is what differentiates suicide from other forms of taking life. Self-agency is, therefore, a necessary condition for labeling an act a suicide. 
But, is it enough to say that a suicide is an "act of taking one's life?"

Case 1-2: Brian, a collector of rare guns, is cleaning one of his guns when he accidentally pulls the trigger, killing himself instantly.

Brian may be said to have taken his own life, but was his death a suicide? Distinctions are commonly drawn between suicides and accidents. Suicide implies, at the very least, that the agent have some knowledge that the act will with reasonable certainty result in his or her own death. This knowledge is another necessary condition for a definition of suicide.

For some, the conditions of self-agency and of knowledge of the probable consequences of the act, when taken together, provide the sufficient conditions for a definition of suicide.

Émile Durkheim, in his aforementioned work, offers this definition of suicide:

The term suicide is applied to all cases of death resulting directly or indirectly from a positive or negative act of the victim him self, which he knows will produce this result.

Durkheim's definition is, however, so broad that it includes cases not normally considered instances of suicide. For example, it is by now common knowledge that smoking greatly increases the risk of developing a number of fatal conditions. Would smoking be an example of an act of suicide? A death resulting from lung cancer 
produced by smoking would seem to fit Durkheim's criteria for suicide.

Smoking has been described as "slow sucide," but the fact that it has been labeled this and not "suicide" should cause us to be circumspect. There is something about the act of smoking that sets it apart from acts that are deemed to be suicide. Perhaps the reason we are hesitant to call a death caused by smoking a suicide is because the dying process occurs over such a long period of time. In order to check this hypothesis, let us contrast smoking with another case.

Case 1-3: Christine is reading on the beach while her son is swimming in the ocean. Suddenly the boy starts screaming for help. Christine looks for someone to help because she cannot swim. Nobody can be found so she rushes into the rough water herself. While attempting to rescue her son, Christine drowns.

Like the smoking example, the agent in this case knows that her act will with reasonable certainty result in her death. This case is different from the smoking case in that the act and the death occur within a short period of time. Does this difference lead us to classify Christine's death as a suicide? The answer appears to be "no." Neither the smoking case nor this case is usually regarded as a case of suicide. While the time lapsed between the act and the death may indicate that a death was or was not a suicide, a stronger reason 
can be given as to why these cases do not qualify as suicides.

The main difference between Alice's act in Case 1-1 and Christine's act in Case $1-3$ has to do with the intentions of the agents. In the first case, the agent intends her own death. In the second case, Christine intends only to rescue her son; her death is an unintended effect of her act. Intentionality is another necessary condition for an act to be considered a suicide.

The addition of intentionality as a necessary condition, while helping to reflect our considered judgment on the subject, raises as many questions as it helps to answer. It is precisely for this reason that Durkheim did not include intentionality as part of his definition of suicide. He writes:

Intent is too intimate a thing to be more than approximately interpreted by another. It even escapes self-observation. How often we mistake the true reasons for our acts. We constantly explain acts due to petty feeling or blind routine by generous passions or lofty

Durkheim may be accurate in his observation, but the difficulty we have in discerning an agent's true intentions should not lead us to abandon it as a necessary condition for suicide. It should only make us more careful in our use of the terms "intention" and "suicide." We are still faced with the problem of determining 
the intention of the agent. To complicate matters even further, it is not unusual for an agent to have several intentions for a single act. There is, unfortunately, no simple solution to this problem. The following case has become a classic in this context:

Case 1-4: Captain Lawrence E.G. Oates was a member of the Scott Expedition to the South Pole. By the time the expedition was returning from its destination, Captain Oates was badly frostbitten. He was aware that his condition was hampering the progress of his comrades, thus gravely endangering their lives. One day he left the camp, walked into the blizzard, and never returned.

Was Captain Oates' leaving the camp an act of suicide? There is disagreement in the literature as to. whether or not this is a case of suicide. According to R.F. Holland, Oates' death was not a suicide because, "in Oates's case, I can say 'No, the blizzard killed him.' Had Oates taken out a revolver and shot himself I should have agreed he was a suicide."1l Holland's argument is that Oates' death was not a suicide because his intention was to assist his comrades and because he did not use an active means in his death.

Others, however, claim that Oates' death was a suicide. Beauchamp argues, "Although the climactic conditions proximately caused his death, he brought about the relevant life-threatening condition causing his death (exposure to the weather) in order that he 
die."12 In response to Beauchamp, I would want to argue that it is not clear that Oates walked into the blizzard "in order that he die." Beauchamp's claim seems too strong. Perhaps the strongest argument that one can put forward in support of the position that Oates' death was a suicide is advanced by Glanville Williams: "It may be doubted... whether Oates, brave man that he was, would have welcomed a protracted existence alone and unprotected in the polar snow, even if this had been possible." 13

The Oates case is an example of a death that had multiple effects. Each effect points to the possible existence of multiple intentions. Because the intention to die may be one of those intentions, it may be said that it is likely that Oates' death was a suicide. But, because we cannot know the precise nature of Oates' intentions, it is unlikely that the question of whether or not his death was a suicide will ever be resolved. There is a class of cases in which the intention to die may be present, yet we are still reluctant to describe these cases as suicides. These cases would include instances in which an agent intends to die for other-regarding reasons. We usually describe such cases as sacrificial or heroic, and not as acts of suicide.

Case $1-5^{\prime \prime}$ Miss E. was a spy who was captured by the enemy. She knew of top secret plans 
that the enemy was anxious to obtain. The interrogator threatened Miss E. with torture if she did not reveal the information. Miss E., however, did not wish to reveal the plans or suffer the pains of torture. She swallowed a capsule filled with poison that she carried with her. She died instantly.

In this case, it is clear that the agent had multiple intentions, one of them being the intention to die as a necessary means for not revealing information and avoiding torture. Because the intention to die is present, Miss E.'s death is a suicide. Many have argued, however, that the agent's death is a heroic fulfillment of her duty and ought not to be considered a suicide. Some have even held that the agent in this case becomes her own enemy and her death is more accurately described as a justified killing. The uneasiness felt in connection with this case, as evidenced by the attempts at creative psychology, is probably due to weightier concerns than whether or not this is a case of suicide. What is important to note about this case for this discussion is that it fulfills the necessary criteria that would make it a suicide: self-agency, knowledge of the risk of death, and intention to die. While a moral assessment of this case might indicate that the agent was justified in acting as she did, her act was, nonetheless, an act of suicide.

Self-agency, knowledge of the risk of death, and the intention to die are all necessary conditions for 
a definition of suicide. There are other conditions that are often associated with suicide but, upon examination, it seems evident that they do not constitute necessary conditions. The time between the act and the death, as noted above, turned out not to be a necessary condition.

Another factor that is often mentioned in connection with suicide has to do with the means used. The active means--passive means distinction is often seen as an important one in defining suicide. Holland, for example, admits that if Captain Oates had shot himself, he would have been willing to label Oates' death a suicide. The fact that Oates merely walked away from the camp into the blizzard and did not actively take his life leads Holland to conclude that Oates' death was not a suicide.

In the medical context, the active means--passive means distinction is sometimes framed in terms of the relation between suicide and refusal of treatment. On the one hand, there appears to be little difference between the individual who cuts his wrists in order to die and the one who, after accidentally cutting his wrists, refuses to seek or accept medical treatment because he wishes to die. As Joseph Fletcher argues, "Not to do anything is a decision to act every bit as much as deciding to do what we would accomplish by 'not' acting."14 In this sense, some refusal of treatment 
cases can be suicides. On the other hand, there are some cases of refusal of treatment that are commonly contrasted with suicide. When a person who has a terminal disease in which there is clear evidence that death is imminent and unavoidable refuses treatment, thereby allowing herself to die, we do not usually label that death a suicide. If, however, that same person shot herself with a revolver in order to hasten her death, we might be more willing to label that death a suicide. Beauchamp and Childress note,

The more we have patent cases of actions that intentionally and actively cause one's own death, the more we are likely to classify them as suicide; but the more the context is one of merely allowing one's own death when a fatal condition is present, the less inclined we are to call the act a suicide.15

It is those cases which fall in the middle of this continuum that present difficulties for a definition of suicide. The categories of suicide and refusal of treatment appear to intersect, but not overlap. Whether or not a particular refusal of treatment is suicide will depend on the facts of the case.

The active means--passive means distinction and the refusal of treatment--suicide distinction, while sometimes helping to reveal an agent's intentions, are not a necessary part of a definition of suicide. As Childress concludes on the subject: "It is not necessary 
to draw a hard and fast line between suicide and refusal of life-saving medical treatment. Wherever the line is drawn for conceptual and moral reasons, important issues will emerge from both actions."16

I now wish to provide a definition of suicide that will accord with our ordinary understanding of the term without including any normative claims. This definition is based on a distinction that is often drawn between suicidal acts and acts of suicide.

An act may be said to be suicidal without being an act of suicide if the following conditions are present: (1) The act must, with reasonable certainty, lead to the death of the agent; and (2) The agent knows that (1) is the case. In order for an act to be an act of suicide, an additional condition needs to be met: (3) The agent engages in the act with the express purpose of bringing about his own death. 17

This definition of suicide has the virtue of not including any moral judgment while, at the same time, making sense of our ordinary use of the term. We often use, for example, the adjective "suicidal" to describe an act engaged in by an agent who is consciously aware of the risk of probable death. It also implies that the agent does not intend her own death. For an act to be considered an act of suicide, this intention must be present. It does not matter whether the death was intended as an end in itself or as a necessary means to another end, only that it was intended by the agent. 
By adopting this definition, it will not make the judgment as to whether or not a given act is a suicide any easier, but it will help to indicate why the borderline cases are problematic.

With this definition of suicide stipulated in advance, I wish now to turn to a discussion of the morality of suicide.

Notes

1 Émile Durkheim, Suicide: A Study in Sociology, trans. John A. Spaulding and George Simpson (New York: The Free Press, 1951), p.41.

2 For an interesting and extensive discussion of the history of the terms used to describe suicide in several languages, see David Daube, "The Linguistics of Suicide," Philosophy and Public Affairs 1 (Summer 1972): 387-437.

3 Ibid., p.390.

4 Tom L. Beauchamp and James F. Childress, Princi$\frac{\text { ples of Biomedical Ethics, }}{\text { University Press, } 1983 \text { ) }}$ 2nd ed. (New York: $\frac{\text { Oxford }}{\text { Und }}$

Joseph Margolis,
(Columbus, Ohio: Chativities: The Limits of Life (Columbus,
Co., 1975), p.35.

6 "Suicide," in New Catholic Encyclopedia, prepared by an editorial staff at the Catholic University of America (Palatine, Illinois: Jack Hearty \& Assoc., Inc., 1981).

7 Karen Lebacqz and H. Tristam Engelhardt, "Suicide," in Death, Dying and Euthanasia, ed. Dennis J. Horan and David Mall (Washington, D.C.: University Publications of America, 1977), p.673. 
8 The Compact Edition of the Oxford English Dictionary (New York: Oxford University Press, 1971).

9 Durkheim, Suicide: A Study in Sociology, p.44.

10 Ibid., p. 43 .

11 R. F. Holland, "Suicide," in Moral Problems: A Collection of Philosophical Essays, ed. James Rachels (New York: Harper and Row, 1971), p.353.

12 Tom L. Beauchamp, "Suicide," in Matters of Life and Death, ed. Tom Regan (New York: Random House, 1980),

13 Glanville Williams, The Sanctity of Life and the Criminal Law (New York: Alfred A. Knopf, 1957), p.269.

14 Joseph Fletcher, "In Defense of Suicide," in Suicide and Euthanasia: The Rights of Personhood, ed. Samuel E. Wallace and Albin Eser (Knoxville, Tennessee: The University of Tennessee Press, 1981), p.48.

15 Beauchamp and Childress, Principles of Biomedical Ethics, p. 94 .

16 James F. Childress, Who Should Decide? Paternalism in Health Care (New York: Oxford University Press, 1982), pp.163-164.

17 Except for one modification, this definition is drawn from Eike-Henner W. Kluge, The Practice of Death (New Haven, Conn.: Yale University Press, 1975), p.103. The modification is making (1) and (2) the necessary conditions for a suicidal act, which would distinguish it from other potentially lethal acts. Kluge only requires that one or both conditions be present for an act to be considered suicidal. 
CHAPTER II: The Contemporary Debate: Some New Variations on Some 01d Themes

And what shall he suffer who slays him who of all men, as they say, is his own best friend? I mean the suicide, who deprives himself by violence of his appointed share of life, not because the law of the state requires him, nor yet under the compulsion of some painful and inevitable misfortune which has come upon him, nor because he has had to suffer from irremediable and intolerable shame, but who has from sloth or want of manliness imposes upon himself an unjust penalty.... They who meet their death in this way shall be buried alone, and none shall be laid by their side; they shall be buried ingloriously in the borders of the twelve portions of land, in such places as are uncultivated and nameless, and no column or inscription shall mark the place of interment.

Plato, Laws, Book IX, 873

For mere living is not a good, but living well. Accordingly, the wise man will live as long as he ought, not as long as he can. He will mark in what place, with whom, and how he is to conduct his existence, and what he is about to do. He always reflects concerning the quality, and not the quantity, of his life. As soon as there are many events in his life that give him trouble and disturb his peace of mind, he sets himself free. And this privilege is his, not only when the crisis is upon him, but as soon as Fortune seems to be playing him false; then he looks about carefully and sees whether he ought, or ought not, to end his life on that account. He holds that it makes no difference to him whether his taking-off be natural or self-inflicted, whether it comes later or earlier. He does not regard it with fear, as if it were a great loss; for no man can lose very much when but a driblet remains. It is not a question of dying earlier or later, but of dying well or ill. And dying well means escape from the danger of 1 iving ill. 
But this we affirm, this we maintain, this we every way pronounce to be right, that no man ought to inflict on himself voluntary death, for this is to escape the ills of time by plunging into those of eternity; that no man ought to do so on account of another man's sins, for this were to escape a guilt which could not pollute him, by incurring great guilt of his own; that no man ought to do so on account of his own past sins, for he has all the more need of this life that these sins may be healed by repentance; that no man should put an end to this life to obtain that better life we look for after death, for those who die by their own hand have no better life after death.

St. Augustine, The City of God, Book I, 26

In the history of philosophy and religion, there has been little agreement concerning the moral status of suicide. Attitudes toward suicide have ranged from approbation to condemnation. It can be said that what would guarantee an individual an eternal place with the gods according to one tradition is the very same thing that would guarantee eternal damnation according to another.

Three main positions, however, have emerged concerning the morality of suicide. These positions are represented by the three passages which open this chapter. The Greeks, while rejecting the radical individualism underlying most suicides, did recognize certain exceptions to a general prohibition of suicide.

Another position was put forward by the Stoics, 
Epicureans, and later, the Romantics of the nineteenth century. These groups extolled the human virtue of self-determination, especially in the face of misfortune. Suicide was often a noble act which could help preserve one's honor. According to this position, suicide was something that ought not to be prohibited. It was, instead, to be viewed as a "privilege" and an appropriate response to many of life's crises.

In stark contrast to the words of Seneca stand those of St. Augustine. In order to appreciate St. Augustine's position, it must be remembered that he was writing at a time when the church was confronted with a crisis that called for immediate attention. While the earlier persecutions made martyrs out of many Christians, there were Christians living at the time of St. Augustine who were seeking voluntary martyrdom with a fanatical yearning for death. For these Christians, particularly the Circumcellions, death was seen as an attractive option in light of the misery of this life conjoined with the promise of eternal happiness after death. These groups were interpreting Christian teachings in such a way as to support suicide and suicidal behavior. St. Augustine recast these church teachings into an absolute prohibition of suicide in the hope that this prohibition would help curtail the excesses of certain groups who were aggressively seeking 
their own death.

Since the time of St. Augustine and up until recently, the absolute religious prohibition of suicide has been echoed in many legal codes. For centuries, in Western culture, suicide was, for the most part, looked upon as a criminal act. Severe penalties, including the dishonoring of the corpse and the forfeiture of one's estate, were traditionally attached to suicide. Recently, however, the absolute prohibition position has been challenged on religious, moral, and legal grounds.

Since it would be impossible to review all of the arguments that have been offered for and against the moral permissibility of suicide, the method used in this chapter will be to identify and analyze the basic moral principles which converge in a discussion of suicide. It is believed that such an analysis can help generate a defensible position concerning the morality of suicide.

Before beginning an analysis of the moral principles involved in suicide, some preliminary comments are necessary. As was stated in the first chapter, suicide is a broad term that can include many different types of acts. For the purpose of this discussion, a distinction will be drawn between two types of suicide. This distinction is taken from a typology of socially 
determined conduct developed by Max Weber. ${ }^{1}$ Suicide

may, first, be determined rationally and oriented toward an end. In that case it is determined by the expectation that objects in the world outside or other human beings will behave in a certain way, and by the use of such expectations as conditions of, or as means toward the achievement of the actor's own, rationally desired and considered, aims. This case will be called purpose-rational (zweckrational) conduct. 2

In purpose-rational conduct, the agent's act is aimed at bringing about a specific end. The language of cause and effect, instrumentality, and efficiency is often associated with this type of conduct.

I have heard of a post-war writer who, after having finished his first book, committed suicide to attract attention to his work. Attention was in fact attracted, but the book was judged no good.

Albert Camus, The Myth of Sisyphus

Case 2-1: Mr. Allen, a 35 year-old father of two is suffering from Huntington's Chorea. This disease has progressed to the point where he experiences radical mood changes, great pain, and a loss of physical control. He decides to attempt suicide in order to relieve his family of the financial and emotional burden his illness has put on them, as well as, to relieve himself of the physical and mental anguish.

In this case, Mr. Allen views his suicide as a means of pursuing specific ends: to no longer be a financial and emotional burden on his family and to no longer 
experience physical and mental pain. His suicide is purpose-rational.

There is another type of suicide that is not accurately described as a means to an end. This type of suicide

may be determined...by the conscious faith in the absolute worth of the conduct as such, independent of any aim and measured by some standard as ethics, aesthetics, or religion. This case will be called value-rational (wert-
rational) conduct. 3

Where the first type of suicide is designed to be instrumental, value-rational suicide is meant to be expressive or communicative of some feeling or value. The Buddhist monks who killed themselves by self-immolation in protest of the war in Vietnam are examples of individuals who took their own lives not so much as for pursuing an end as for expressing an attitude. Perhaps the most recent and most publicized case of a suicide that was, for the most part, value-rational is the case of Jo Roman.

Case 2-2: In 1975, Jo Roman, an artist, decided that she would begin plans for her suicide that was to take place in 1992, when she would be 75. She wrote, "I'd aim for my exit date to predate discomfort of intensity which might diminish my chance of CREATING ON MY OWN TERMS THE FINAL STROKE OF MY LIFE'S CANVAS "4

In 1978 it was discovered that she had breast cancer. Roman decided to move up the date of her suicide. Through a book, a video- 
tape, and several interviews, she hoped to show the public that rational suicide "makes possible a truly ideal closing of one's life span."

On 10 June 1979, after completing her "life sculpture," a pine box filled with personal objects, she took a fatal dosage of pills. The report of the medical examiner of New York concluded that there was "no evidence the cancer had spread beyond the lymph nodes to any vital organ."6

Roman's suicide was not purely value-rational because it was partly intended as a means of avoiding a state of dependence. It was, however, value-rational in that Roman did wish to communicate to the public that suicide could play a valuable role in one's life.

Another issue that is critical for a discussion of the morality of suicide has to do with whether or not suicide can be a rational act. The claim that suicide can be a rational type of conduct has been challenged by the medical model of suicide that has been the predominant model of the last century. This model has tended to move the discussion of suicide from a religious or moral context to a medical one.

Instead of a post hoc judgment--whether it is theological, moral, or legal--there is an effort to diagnose and prevent: rather than trying to discourage suicide by means of threat (of worldly or divine punishment), there is an attempt to eradicate the causes of suicide. Treating has replaced preaching! Like many other phenomena in our culture (madness is a good example) suicide has undergone a deep process of medicalization. 7 
The work of Sigmund Freud, for example, has been particularly influential in this regard. 8 According to Freud, the agent who attempts suicide is bent not so much on killing herself as she is on killing another person who she has incorporated within herself. Suicide, thus, is viewed as a manifestation of a subconscious conflict. The agent is diagnosed as suffering from a psychological disorder which requires treatment. The possibility of a rational suicide, according to this model, is denied. Because rationality is denied, the question of whether or not the agent is acting morally is not germane.

In opposition to the medical model, there has been a growing movement to recognize the possibility of rational suicide. This movement has derived much of its force from the moral dilemmas that have emerged as a result of advances in biomedical technology. There is no doubt that advances in medicine have greatly contributed to the preservation and prolongation of 1ife. Some technologies, however, are able to promote the former only by making the latter unbearable. It is argued against those who support the medical model of suicide that suicide, in at least these cases, can be rational. This claim is not meant to imply that those people who find themselves in that position ought to attempt suicide. It is only meant to indicate that 
suicide can be a rational choice in some cases. And, because of what is at stake in suicide, it is a choice that can and ought to be discussed in moral terms.

Richard Brandt, a proponent of rational suicide, argues: "A decision to commit suicide may in certain circumstances be a rational one. But a person who wants to act rationally must take into account the various possible 'errors' and make appropriate rectification of his initial evaluations."9 In response to this position, Hauerwas wonders "how anyone could take account of all relevant variables and future possibilities in considering suicide."10 Hauerwas is indeed correct in arguing that one cannot take account of all factors in considering suicide, but it is impossible to take account of all factors when considering any act. We often act with incomplete information and uncertain expectations. For an act to be rational means that it is performed after careful consideration of the information available to the agent, and not after consideration of " all relevant variables and future possibilities" since such information is rarely available. A tacit claim in Hauerwas' argument is that things might get better for the individual contemplating suicide. Things may get better, but then again things may get worse. There are many people who can look back on their lives and honestly admit that, at a given point, they 
would have been better off dead.

The point which Brandt and others make is that we cannot automatically assume that all suicides point to mental illness and are, therefore, irrational. Joel Feinberg's argument concerning rationality and voluntary slavery can be applied to suicide with equal force: it may be true that suicide is irrational, "but if this is a truth it is not an a priori one but rather one that must be tested anew in each case by the application of independent, non-circular criteria of mental i11ness. "11

Hauerwas eventually concludes on the discussion of the rationality of suicide that "suicide can be, and often is, a rational decision of an 'autonomous' agent, but I do not, therefore, think it is justified."12 Whether or not suicide can be morally justified will be the focus of the remainder of this chapter.

What does it mean to say that an act is justified? What it means for an act to be justified is best understood when it is contrasted with an act that is excused.

The effect of an excusing circumstance is to put the wrongful act ex causa, outside the court of moral verdict at all. We still disapprove of the act, and consider it unwarranted; we do not think that the agent was entitled to do it, but simply recognize that some condition necessary for personal responsibility was lacking in him.13

If an act is excused, the act is considered to be wrong 
but the agent is not held responsible. "Many who would absolutely condemn suicide fail to distinguish the objective wrongness of an action from the moral excusability and even praiseworthiness of that same action."14 This point can be illustrated if we imagine a man who takes his own life because he incorrectly assumes that he has a terminal condition which requires treatment that will emotionally and financially drain his family. Is this act of suicide wrong? Yes. Did the man act reprehensibly? No. In this instance, the agent was not blameworthy. We may even go so far as to say that his act was praiseworthy.

In contrast, if an act is justified, the act is judged to be right or correct in that particular set of circumstances.

The effect of a justifying circumstance is to justum facere an (otherwise wrongful) act, so that it becomes good or at least permissible: lawful.15

To say that an act is justified is to make a much stronger claim than to say that it is excused. For an act to be justified, the reasons that can be given for the performance of that act must outweigh those that can be given against its performance. In moral discourse, it is to say that an act is morally right. This thesis is concerned with whether or not suicide can be morally justified. 
In attempting to formulate a defensible position concerning the morality of suicide, the method of analysis employed will be to examine one's moral rights and duties as they are generated by major moral principles. It should be noted, however, that the use of a rights model as a method of analysis has been attacked as inadequate by some philosophers, especially those who would advocate a virtue model. James Bogen, for example, argues that "an adequate treatment of the morality of suicide must deal with questions which cannot be illuminated by a consideration of rights, obligations, and duties."16 According to the virtue model, the primary question to be answered by moral reflection is not "What should I do?", but, "What kind of person ought I to be?" The virtue model focuses its primary attention on the agent rather than the act. Proponents of the virtue model claim that to say an agent "has a right to take his own life is to say nothing about whether he should (whether it would be good or bad for him to do so)...."17 Hauerwas adds that an analysis of duty, obligation, and rights grounded in principles does not capture the essence of what it means to live the moral 1 ife.

Our moral lives are not simply made up of the addition of our separate responses to particular situations. Rather we exhibit an orientation that gives our life a theme through which the variety of what we do and 
do not do can be scored. To be agents at all requires a directionality that involves the development of character and virtue. Our character is the result of our sustained attention to the world that gives a coherence
to our intentionality.18

John Ladd rejects the notion of the primacy of moral rights and duties and argues instead for an ethics based on responsibility and relationships. 19 Ladd's criticism of decisions based on rights is that

they do not involve taking into account (risks and benefits, other relationships, concerns, needs, and abilities of persons affected by and affecting the decision), and they do not involve the same kind of weighing, deliberation, judgment, etc., that is called for in cases of responsibility. Indeed, one of the special and distinctive logical properties of a right is that normally, in determining whether to comply with it, one is not permitted to consider any factors other than those directly relating to the status of the right itself and one's ability to do what it requires. 20

It is not clear, however, what distinguishes considerations of the factors directly relating to the status of the right "from considerations, of risk and benefits, other relationships, concerns, needs, and abilities of persons affected by and affecting the decision." It is precisely these considerations which determine the status of a moral right. Moral deliberation using the concepts of duties, obligations, rights and principles is as dynamic as moral deliberation using 
the concepts

for that fact, virtues. Both methods involve a careful determination of the relevant factors, an analysis and weighing of those factors and, finally, the formulation of a defensible moral judgment.

Surely we do appeal to the rights which people have in the justification of action and from this it would seem to follow that any account of moral reasons will be at least incomplete unless due account is paid to the rights of persons. Indeed, discussions of right conduct which neglect rights tend to err in other respects as well, for in neglecting the substantial uses of 'right,' such discussions will ignore some of the more complex features of the procedures of moral justification and offer an anemic and distorted representation of our common moral understanding. 21

A.I. Melden attributes much of the criticism of an ethics of rights to a confusion between "'having a right' and 'being justified by the particular circumstances in a given case in exercising it." 22 To say that an agent has a right to do $X$ does not necessarily mean that when she exercises her right to do $X$, she acts rightly. There is a difference between saying "an agent has a right to do $X$ " and saying "an agent acts rightly in doing $x . "$ The former statement is only one consideration in the decision process.

Beauchamp and Childress note,

Rights and duties do not always fully determine what we should do and how we should do it. 
In particular they do not determine all forms of good, ideal, and virtuous ways of life, many of which are shaped by religious commitments and communities. Such ways, however, should not violate rights and duties (emphasis added). 23

This last sentence is critical to the moral analysis of suicide and other issues. It is necessary to use moral rights and moral duties to establish a common moral ground which can be used to discuss and reslove dilemmas and from which policies can emerge. This need is an especially salient one in a pluralistic society such as our own. There may be more, and there ought to be more involved in reaching a particular moral decision, but moral duties, obligations, and rights help form a moral minimum to which any decision ought to be attentive.

A rights model is preferred because it is better suited to adjudicate competing moral claims especially in a society where there is little agreement as to what constitutes the virtuous life. There are those, like Alisdair MacIntyre, who, in opposition to the rights model, argue that it is impossible to adjudicate claims about rights because of the absence of shared beliefs and values. 24 This position, however, seems to be too extreme. MacIntyre's criticism seems to apply to some rights more than others. On the whole, there is more 
agreement about rules, in the form of procedural constraints, procedural requirements, and negative rights than MacIntyre appears to acknowledge. It is this very agreement, for example, that forms the basis for the model of justice developed by John Rawls in A Theory of Justice. 25

Virtues and responsibility play an important role in the moral life. An examination of the rights model and the virtue model reveals that the two models are not antagonistic and that their differences are often more a matter of emphasis and structure than anything else. In many instances, the rights model and the virtue model render identical decisions about a particular case. A rights model focusing on the act and not on the character of the agent is, however, ultimately preferred. In short,

While we do count on morally good persons to perceive and to do what is morally right, we also know from experience that persons of good moral character sometimes fail to discern what is right. Furthermore, such persons are often the first to recognize that they do not know what ought to be done. Hence, a discussion of the morality of acts remains important, indispensible, and primary in establishing what morally good people ought to do. 26

Suicide appears to be one of those instances in which even morally good persons have difficulty in discerning what ought to be done. It is a complex issue 
that does not lend itself to a ready solution, but it also need not force us into a kind of moral catalepsy. By analyzing the major moral principles 27 that are relevant to a discussion of suicide, it is possible to construct a coherent and defensible position.

We will begin this analysis by first examining the principle of utility. The analysis will then move on to those principles which are more deontological in character.

\section{The Principle of Utility}

Utilitarians generally contend that the sole and ultimate standard of the morality of an action is the good or value it produces. An action is morally good or right if it produces the greatest balance of good over evil, value over disvalue. In this discussion, the principle of utility will not be regarded as the sole moral principle, but only as one moral consideration among several others.

In calculating the net value produced by suicide, it is necessary to consider the consequences of the act for the agent, those closely connected to the agent, and society. In most cases, suicide for an individual would appear to create more disvalue than value. Death is a tremendous harm that is not easily outweighed by other considerations. However, while we generally 
consider death to be a great harm, we do recognize certain kinds of life to be a great harm to an individual and his dignity.

Case 2-3: Mr. Craig, an eighty year-old man, is suffering from glaucoma and cancer and is bedridden in a nursing home. He recently lost his wife and has no living relatives or close friends. He complains about being in great pain, although he is given pain killers. He requests that he be allowed to end his life with dignity.

According to the principle of utility, suicide in this case may create a greater balance of value over disvalue. The agent is in pain and suffers from a condition that will eventually result in more pain and debilitation. Suicide, in this case, would appear to help the agent avoid this further pain and allow him to die with what he believes to be dignity.

Although the principle of utility may indicate that suicide is morally right in the above case, it is rarely found to support such an action when the agent's death will cause harm to others.

It's bad that it is so untidy, there is no denying that, for it bespatters one's friends morally as well as physically, taking them so much more into one's secret than they want to be taken.

\section{Alice James, The Diary of Alice James}

Hauerwas writes, "suicide can be one of the most perverse 
forms of moral manipulation, as it abandons those left behind to their shame, guilt, and grief. Suicide is something like a metaphysical 'I-gotcha!'"28 That one may cause harm to one's family, relatives, friends, and other dependents may be the weightiest and most compelling moral argument against the moral permissibility of suicide.

When suicide is designed merely to cause grief or harm to those left behind, it is almost always the case that it is morally unjustified. But what about the suicide that would appear to benefit others? In Case 2-1, the suicide of Mr. Allen may result in a period of unhappiness and grief for his family and friends, but according to the principle of utility, this harm must be weighed against the possible benefit to be gained. We may not wish to place too much emphasis on the financial benefit, but it cannot be denied that suicide would probably, in the long run, provide the agent and the family with emotional relief. The family would not have to watch a loved one go through a slow and painful death against his wishes.

The principle of utility would also require us to examine the effect suicide would have on society. At one time, the claim that suicide would have a harmful effect on society was one of the strongest reasons that could be given against allowing suicide. Aristotle 
argued :

(H)e who through anger voluntarily stabs himself does this contrary to the right rule of life, and this the law does not allow; therefore he is acting unjustly. But towards whom? Surely towards the state, not toward himself. For he suffers voluntarily, but no one is voluntarily treated unjustly. This is the reason why the state punishes...29

St. Thomas Aquinas argued from a similar position:

(E)very part belongs to the whole in virtue of what it is. But every man is part of the community, so that he belongs to the community in virtue of what he is. Suicide therefore involves damaging the community, as Aristotle makes clear. 30

Both writers begin with a certain metaphysical conception of the state or community and the role of the individual. One was inextricably tied to the body politic and to end one's life was to harm that body. This same claim has been used by kings and governments as grounds for making suicide a criminal act.

A retort to the position of Aristotle and St. Thomas Aquinas was made by David Hume in his classic essay, "On Suicide."

A man who retires from life does no harm to society: he only ceases to do good; which, if it an injury, is of the lowest kind. All our obligations to do good to society seem to imply something reciprocal. 31

Hume goes on to add, 
But suppose that it is no longer in my power to promote the interest of society; suppose that I am a burden to it; suppose that my life hinders some person from being much more useful to society: in such cases, my resignation of 1 ife must not only be innocent, but laudable. 32

The claim that suicide is wrong because of the harmful effects it will have on society is not without its modern-day adherents. Hauerwas contends,

Just as we work to live in a manner that continues our communities of trust, so we must die in a way that provides for healthful and morally sound grief for those whom we leave behind. The miracle of trust is both a reason for living and a reason for dying in one way rather than another. 33

Hauerwas' position is that suicide undermines the trust and care that must exist between a community and its members. But what is the nature and scope of this duty to care and be cared for? This duty, if that is what it is, appears to be grounded in a religious view of a community which may be subject to debate in a pluralistic society. In fact, there are many who would deny that suicide violates any duty towards society. Glanville Williams, for example, denies "that the individual owes any duty to society to stay alive." 34 But the potential effect of suicide on the community ought to be a consideration when one contemplates suicide, although it is a weak consideration when compared to a consideration 
of the effects on oneself and others.

In short, the principle of utility would appear to indicate that suicide is prima facie wrong, but that in certain circumstances it may be justified. Suicide is, in most cases, morally wrong because of the great harm of death to the agent and the grief and guilt which often afflict those left behind. But the principle of utility does not lend itself to an absolute prohibition of suicide because there may be cases in which suicide would lead to a greater balance of benefit over harm.

\section{The Principle of Respect for Persons}

The principle of respect for persons is understood to mean that individuals should be allowed to be selfdetermining agents, making their own decisions and choices free from interference when their own interests are at stake. This principle is based on the presumption that individuals are the best judges of what is in their own best interest. In a pluralistic society, where there are a number of competing views as to how life ought to be lived, governments have found it important to protect and foster private responsibility and personal choice.

Respect for persons requires that we recognize individuals as "entitled to determine their own destiny with due regard to their considered evaluations of the 
world, even if it is strongly believed that their evaluation or their outlook is wrong and potentially harmful to them." 35 As Childress notes, the principle of respect for persons involves

\begin{abstract}
respecting whatever choices a person makes, at least within the limits set by moral principles and rules. Perhaps it is better to say not that we should respect his ends, but that we should respect his ends, i.e., as his representation of his values, purposes, and choices. 36
\end{abstract}

The claim that one has a right to self-determination whereby one's choices and actions ought to be free from outside interference is the strongest argument in favor of a right to suicide. But one's right to self-determination is a prima facie right which can be overridden if it comes into conflict with stronger competing moral obligations. When applied to suicide, the principle of respect for persons generally leads to the following conclusion: "Persons should be permitted to take their own lives when they have chosen to do so freely and rationally and when there are no other duties which would override this freedom." 37

It has already been argued in opposition to the medical model that one can choose freely and rationally to end one's life. Some of the duties which may come into conflict with one's right to suicide have been mentioned under the principle of utility and others 
will be examined in the remainder of this chapter.

In the next chapter, I will examine the conflict that arises when a bystander is confronted with an individual intent on ending her own life. The bystander has the problem of reconciling the duty to respect the free and rational choices of others and the duty to assist others and preserve life.

The principle of respect for persons is the ground for a right to suicide. It is a prima facie right in that it can be overridden by stronger claims. But, although "some suicides may violate the rights of other persons,...equally certainly some suicides do not." 38

\section{The Principle of Human Worth ${ }^{39}$}

The principle of human worth can be understood in a number of ways. Some philosophers argue that the principle of human worth is derived from another moral principle, namely, the principle of nonmaleficence which, in its broadest sense, is understood to mean that evil or harm ought not to be inflicted. Others argue that the principle of human worth is not derived from a more fundamental moral principle but is, itself, an independent moral principle. Central to any understanding of this principle, however, is the claim that life has an intrinsic value and, therefore, ought not to be destroyed. Any act that intentionally terminates life is morally 
wrong. According to this principle, an act of killing is morally wrong not because of the harm it may create or because it violates the principle of respect for persons, but because life has a value in itself that killing destroys. Suicide would be wrong, according to the principle of human worth, because it destroys life's intrinsic value.

The strongest interpretation of the principle of human worth would prohibit killing of any kind--killing in war, self-defense, and capital punishment. There are some who would subscribe to this interpretation, but most ethical systems find killing, in at least some of these instances, to be morally permissible. Thus, there may be other moral considerations which can override the rule against taking life.

The rule against intentionally terminating a human life is generally considered not to be an absolute rule. It is a rule that ought not to be easily overridden in the making of a moral judgment and it is, therefore, perhaps best to view the rule against intentionally terminating a human life as prima facie binding, i.e., it is a strong claim that can only be overridden when stronger competing claims exist. Those who claim, for example, that the principle of human worth is derived from the principle of nonmaleficence argue that while death is always harm, when all factors are taken into 
consideration, death may in some cases not result in a net harm. For instance, a duty grounded in the principle of utility and the principle of respect for persons may, in a particular set of circumstances, outweigh the duty generated by the principle of nonmaleficence.

The principle of human worth forces an agent contemplating suicide not only to examine and weigh the potential effects of suicide but also to provide strong moral reasons for overriding the rule against intentionally terminating human life. For some, it is impossible to produce such a justification. Others, however, while admitting that it may be rare to be able to provide such a justification, recognize cases in which it may be possible to do so.

\section{Aquinas and Kant on Self-love}

Another argument that is often advanced against the moral permissibility of suicide is that suicide violates one's duty of self-love. St. Thomas Aquinas argues this point from a natural law position.

(E) verything naturally loves itself, and it is for this reason that everything naturally seeks to keep itself in being and to resist hostile forces. So suicide runs counter to one's natural inclination, and also to that charity by which one ought to cherish oneself. Suicide is, therefore, always a mortal sin in so far as it stultifies the law of nature and charity. 40 
It can be asked of Aquinas whether there may be instances in which one's natural inclination to keep oneself in being and one's natural inclination to resist hostile forces come into conflict. The natural inclination to preserve oneself is not the only natural inclination. It is just as natural for human beings to seek to avoid pain. Medical technology has progressed to the point where it is now possible to preserve life but only at the cost of subjecting the patient to the "hostile forces" of physical, emotional, and financial anguish.

Immanuel Kant uses the notion of self-love to generate another argument against suicide. Where Aquinas argues that suicide runs counter to one's natural inclination, Kant contends that one cannot universalize a maxim in favor of suicide.

A man feels sick of life as the result of a series of misfortunes that has mounted to the point of despair but he is still so far in possession of his reason as to ask himself whether taking his own life may not be contrary to his duty to himself. He now applies the test, 'Can the maxim of my action really become a universal law of nature?' His maxim is 'From self-love I make it my principle to shorten my life if its continuance threatens more evil than it promises pleasure.' The only further question to ask is whether this principle of self-love can become a universal law of nature. It is then seen at once that a system of nature by whose law the very same feeling whose function (Bestimmung) is to stimulate the furtherance of life should actually destroy life would contradict itself and consequently could not subsist as a system 
of nature. Hence the maxim cannot possibly hold as a universal law of nature and is thereof all duty. 41 opposed to the supreme principle

Kant's claim is that the principle of self-love contradicts a maxim to shorten one's life. This claim, however, only makes sense if the principle of self-love is interpreted to mean the prolongation of life. While self-love is generally understood to include a desire to prolong one's life, it includes much more. The desire to live is accompanied by a desire to live with meaning and dignity. One's love of life, therefore, includes a qualitative as well as a quantitative dimension. Unfortunately, the mere prolongation of life does not necessarily entail a commensurate prolongation of a satisfactory quality of life.

Aquinas and Kant correctly argue that there exists a duty not only to respect the lives of others, but also to respect and love one's own life. Their arguments. for a prohibition of suicide, however, are ultimately inadequate because of what they fail to take into consideration when using the concepts of natural inclinations and self-love. 
Some Theological Arguments

0! that this too too solid flesh would melt, Thaw and resolve itself into a dew;

Or that the everlasting had not fix'd

His canon 'gainst self-slaughter! 0 God--

How weary, stale, flat, and unprofitable

Seem to me all the uses of this world.

\section{Shakespeare, Hamlet}

From the above discussion, it can be seen that there are no absolute philosophical arguments against suicide. In fact, it can be said that the strongest claims against the practice of suicide have been, in the main, not moral but religious. Where humanistic moral arguments fail to provide an absolute prohibition of suicide, theologically based arguments tend to be more convincing. This claim can be substantiated by observing that when religious values lose their force in society, legal and social barriers toward suicide tend to be weakened. This phenomenon has occured in Great Britain and the United States over the past two hundred years.

In this section, I wish to examine and assess the religious objection to suicide as it has emerged from the Judeo-Christian tradition. Many arguments concerning the morality of suicide dismiss theological arguments because they are grounded in religious beliefs and not philosophical ones. I wish to include theological argu- 
ments because of the influence they have exerted in philosophical, legal, and societal attitudes throughout history.

According to one theological argument, suicide is wrong because it usurps God's power and authority over all life. Kant argues,

So long as we remember the truth that it is God's intention to preserve life, we are bound to regulate our activities in conformity with it. We have no right to offer violence to our nature's powers of self-preservation and to upset the wisdom of her arrangements.42

This argument raises at least two important points. First, it raises an epistomological question concerning how and with what degree of certainty we can determine what God's intentions are. Secondly, even if it is granted that it is God's intention that life be preserved, does this necessarily mean that suicide is to be prohibited absolutely? If it is our duty to preserve life in all circumstances, then it would appear that not only suicide, but such practices as war and capital punishment ought also to be proscribed. It is not clear that scripture or tradition has found such practices to be intolerable, and it is therefore not clear that suicide is prohibited by this argument.

Another theological argument can be found in the third part of Aquinas' tripartite argument against 
suicide. In it, Aquinas argues that

life is a gift to man by God, and it is subject to Him who is master of death and life. Therefore, a person who takes his own life sins against God, just as he who kills another's slave injures the slave's master or just as he who usurps judgment in a matter outside his authority also commits a sin. And God alone has authority to decide about life and death, as he declares in Deuteronomy, 'I kill and I make alive. 143 ,

The claim that life is a gift from God and that suicide is therefore prohibited has been challenged for a variety of reasons. Chief among the objections to this claim is that "a gift which we cannot reject is not a gift."44 Kluge also points out, "A gift can only be given to someone. It cannot be that someone, where both the receiver and what is received are one and the same entity."45 Hauerwas replies to these arguments by claiming that they miss the significance of the language of gift. According to Hauerwas, the focus ought to be on the giver and not the gift: "Life is a gift exactly because the character of the giver does not require that the gift be given at al1."46 Although Hauerwas may be correct in his assessment of the giver of a gift, he does not adequately account for the incongruities between 1 ife and a gift.

It has also been argued that while life may indeed be a gift, it does not necessarily mean that suicide is an evil. Many individuals, in particular those whose 
suicide is value-rational, view suicide as a chance to exercise the freedom which life has bestowed on them. Suicide is also seen by some as a chance to imbue one's life and death with a particular meaning for the agent and for those left behind. For those who suffer, Mary Barrington writes, "The gift is death, a gift we shall all have to receive in due course, and if we can bring ourselves to choose our time for acceptence, so much the better for us, for our family, for our friends and for society." 47 Finally, David Hume asks if the statement that suicide is an evil is the only conclusion that can be drawn from viewing life as a gift.

Do you imagine that I repine at Providence, or curse my creation, because I go out of life, and put a period to a being which, were it to continue would render me miserable?... I thank Providence, both for the good which I have already enjoyed, and for the power with which I am endowed of escaping the ills that threaten me. 48

The Bible is often cited as prohibiting suicide. Although there is no clear interdiction of suicide in the Bible, St. Augustine uses as the point d'appui of his absolutist stance against suicide a particular interpretation of the fifth commandment. ${ }^{49}$

Nay, the law, rightly interpreted, even prohibits suicide, where it says, 'Thou shalt not kill.' This is proved specially by the omission of the words 'thy neighbor,' ...50 
This reading of the fifth commandment allows Augustine to say of the suicide of Judas that "for though he killed himself on account of his crime, his killing himself was another crime." 51

Augustine's interpretation of the fifth commandment is suspect on several accounts. First, it is based on the questionable assumption that what is not included in a commandment is prohibited by that commandment. Augustine recognizes the possibility of lawful killing in the course of a just war; why is it that suicide falls under the commandment not to kill and killing in a war does not?

Secondly, exegetical scholars translate the fifth commandment from the Hebrew to mean "Thou shalt do no murder."52 The killing that is prohibited is unlawful killing. This would help to account for the Hebrew practice of killing in war and capital punishment but it does not imply that suicide ought to be absolutely prohibited.

Thirdly, while Augustine claims that suicide is prohibited by the fifth commandment, there are no passages in the Bible which explicitly condemn suicide. In fact, the old Testament alone recounts seven suicides without explicitly condemning any of them. 53 Perhaps the most interesting of the suicide accounts is that of Razis. 
When the troops were on the point of capturing the tower and were facing the courtyard gate and calling for fire to set the doors alight, Razis, finding himself completely surrounded, fell on his own sword, nobly resolving to die rather than fall into the clutches of these villains and suffer outrages unworthy of his noble birth.

\section{Maccabees $14: 41$}

Not only did Razis take his own life, he was also described as "nobly resolving to die!"

Augustine did attempt to reconcile his absolutist stance against suicide with the story of Samson, whose actions were not condemned in the Bible. Augustine did this by denying that Samson's death was a suicide.

Samson... who drew down the house on himself and his foes together, is justified only on this ground, that the spirit who wrought wonders by him had given him secret instructions to do this. 54

Samson, therefore, did not take his own life but was instead instructed by God to do so. This move solves one problem for Augustine but it at least raises the question of how God could command someone to do something that was intrinsically evil.

Augustine's reading of the fifth commandment as a prohibition of suicide appears to be arbitrary. There can be little doubt that the Judeo-Christian tradition has found suicide to be theologically and morally unacceptable. But it is not clear from the primary text, 
the Bible, that suicide in all instances is to be condemned. There appear to be exceptions to the prohibition of killing and it is questionable as to why certain instances of suicide would also not be exceptional.

Theological arguments may be the strongest arguments that can be offered against suicide but, at the same time, they are the most problematic. The primary text offers no evidence to indicate that suicide is a moral or religious abomination in all cases. On the contrary, there are accounts of suicides in the Bible that are described without including any critical judgment concerning the agents' actions.

In addition, theological arguments may be supported in their most general formations (e.g., it is wrong to commit murder), but their support is less stalwart when they claim that it is God's specific intention that suicide be proscribed absolutely.

Finally, the theological arguments examined in this chapter are grounded in a system of religious beliefs and metaphysical claims that are not shared by all members of society. It is one thing to say that a Christian ought to refrain from suicide because of his or her beliefs, but it is another thing to use those beliefs to form the basis of an absolute prohibition of suicide in a pluralistic society. The Christian attitude toward suicide is built on a particular view of the role of 
God, the community, death, and suffering in one's life. This view ought to be respected by society but it should not be forced on others who hold different beliefs.

Theological arguments have played and continue to play an important part in the judgment that has been attached to suicide throughout history. It is not clear, however, that theological arguments can be used to support an absolute prohibition of suicide.

\section{A Moral Right to Suicide}

It is quite obvious that there is nothing in the world to which every man has a more unassailable title than to end his own life and person.

Arthur Schopenhauer, "On Suicide"

Where does the above analysis of the major moral principles involved in suicide leave us? Theological arguments, while possibly being the most compelling arguments against the moral permissibility of suicide, lack the force of other arguments against suicide if we are discussing the moral status of suicide in a pluralistic society. It may indeed be the case that we ought to refrain from suicide because it usurps the authority and impinges on the domain of God, but such a claim $\varnothing$ rests on certain religious and metaphysical beliefs which are not held as paramount in a pluralistic society. 
We may wish to praise the choice of an individual who decides not to end his own life because of his religious convictions. We at least have a duty to respect that choice. It would, however, be inappropriate to label such a choice as a duty for those who do not share those same convictions. Theological arguments may be compelling arguments for an absolute prohibition of suicide for the members of a particular community, but they do not carry the same weight in determining the morality of suicide in a pluralistic society.

The principle of utility often provides a strong argument against suicide. There is often a duty to refrain from attempting suicide because the harm that it will produce outweighs the possible benefit. It was noted, however, that the principle of utility is a double-edged sword. A utilitarian calculation may, in some instances, dictate that one ought to take one's life. An agent may be hesitant to attempt suicide yet be faced with the possibility that, on the whole, her suicide may produce a greater balance of benefit over harm. The principle of utility would indicate, in such a case, that the agent ought to end her own life despite her hesitancy. That such a possibility might occur is morally disturbing. It is for this reason that the principle of utility is not considered to be the only moral principle involved in the making of a moral judg- 
ment concerning suicide. It is constrained by the other moral principles, namely, the principle of human worth and the principle of respect for persons.

The principle of human worth opposes any form of destruction of life. Because exceptions to this rule are recognized, such as killing in self-defense or a just war, the taking of human life can only be regarded as prima facie wrong. If one opposed all instances of taking life, then it would be possible to defend an absolute prohibition of suicide. "But as soon as any exceptions or qualifications are admitted, it becomes excessively difficult to find any presentable principle upon which these can be admitted while still excluding suicide...."55 One of the reasons that the principle of human worth makes suicide prima facie wrong and not absolutely wrong is because one's duty to preserve life can come into conflict with other duties and rights. A major moral dilemma arises when the duty not to terminate human life conflicts with the right of self-determination. Joseph Fletcher is one of several philosophers who have trouble with the claim that the duty to preserve life must always override the right to act autonomously in choosing suicide because he finds that "you may end your own life for your neighbor's sake, as in an act of sacrificial heroism, but you may not end your life for your own sake. This is a veritable 
mare's nest of nonsense!" 56

The principle of human worth does not generate a duty to preserve human life in all cases. It can be said, therefore, that in some instances one may have a moral right, i.e., a justified moral claim, to override the principle of human worth. In the case of suicide, the moral right is grounded not in the principle of utility but, rather, in the principle of respect for persons. As moral agents, we have a duty to respect the choices and values of other moral agents. This duty even applies when the choice made is to die, even by suicide. As Feinberg notes,

The right to die is simply the other side of the right to live.... I am not renouncing, abjuring, forswearing, resigning, or relinquishing my right to life; quite the contrary. I am acting on that right by exercising it one way or the other. 5

What type of right is the right to suicide? First, it is a prima facie moral right. It may be overridden if it can be shown that the agent is not acting autonomously or that the suicide is unjustifiable in light of the agent's duty not to harm the interests of others. Overriding one's attempt to exercise the right to suicide is called suicide intervention and will be the subject of the next chapter. Suffice it to say, at this point, that there may be cases in which it is morally permissible, and even morally obligatory, to override 
another's moral right to suicide.

Even when a consideration of the value of human life and the potential harms that will be produced are insufficient to override an agent's right to suicide, these considerations still constrain and limit the exercise of that right. For example, Mr. Allen in Case 2-1 may have a right to suicide, but his duty not to harm his family may require him to explain to his family his decision in such a way as to mitigate the harm. He may also choose to end his life in a manner that might affirm the value of life. He could, for example, make his organs available for transplant if they were deemed suitable.

The moral right to suicide is also an in rem right. It is a claim one has against people in general; that is to say, it is not limited to any specific individual. We all have a correlative duty to respect another's right to suicide.

There has been some dispute as to whether the moral right to suicide is a positive or negative right, "A positive right is a right to other persons' positive actions; a negative right is a right to other persons' omissions or forebearances." 58 Those who claim that the right to suicide is a positive right, such as Richard Brandt, argue in the following manner:

The moral obligation of other persons toward one who is contemplating suicide is an instance 
of general obligation to render aid to those in serious distress, at least when this can be done at no great cost to one's self. I do not think this general principle is seriously questioned by anyone, whatever his moral theory; so I feel free to assume it as a premise. 59

There are others, however, who argue that Brandt should not "feel free" to make this assumption. We may have a duty to respect the autonomous choice of another to end his own life, but it does not necessarily follow that we have a duty to render assistance to that same individual in order to facilitate the suicide. There are sound moral reasons that can be given for refusing to assist a suicide. One may ground this refusal in the principle of respect for persons and, even more firmly, in the principle of human worth. One ought not be obliged or have a duty to assist another in a suicide attempt. Such a duty would require too much of a person. The rule against taking human life would also militate against a choice to render assistance in the taking of a human life even though the final agency rests with the one who suicides. Suicide is, therefore, a negative right. It is correlated with the duty of others to refrain from interfering. It is not correlated with a duty to render assistance. State courts and legislatures have generally decriminalized suicide, but whether one possesses a legal right to suicide is unclear. One's legal right to refuse 
life-saving medical treatment is recognized, but it is rare to hear in a court of 1 aw an argument made for a right to suicide. In addition, aiding and abetting a suicide is still considered a crime in many jurisdictions.

In theory, the moral right to suicide should translate into a legal right to suicide based on the right of autonomous individuals to determine their own destinies. In practice, however, there may be good reasons for not promulgating a legal right to suicide, such as helping to preserve the image of the state as the protector and guardian of life. In this context, it would have symbolic value. Even more importantly, research is needed in order to predict the consequences of making a legal right to suicide official. Psychological and social forces may work to pressure the sick and despondent into exercising their legal right to suicide. There is a danger that these groups may be coerced into viewing their right to suicide as a duty to suicide. If there is a chance that this abuse might result, there would appear to be good moral reasons for refraining from making the moral right to suicide a legal right. The time to promulgate a legal right to suicide is when it can be reasonably guaranteed that those who need our assistance and protection most will not be pressured into acting against their wishes. 
From a discussion of a moral right to suicide, we will turn to an examination of the conditions under which it may be morally acceptable to override this right.

\section{Notes}

1 See Max Weber, Max Weber on Law in Economy and

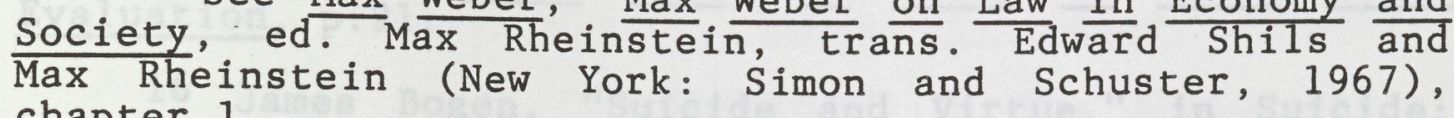
chapter 1 .

\section{Ibid., p.1. \\ 3 Ibid., p.1.}

4 Jo Roman, Exit House (New York: Seaview Books, 1980), p. xvi.

\section{Ibid., p.xv.}

6 Diane K. Shah and Mariana Gosnell, "Rational Suicide?" Newsweek, 2 July 1979, p.87.

7 David Heyd and Sidney Bloch, "The Ethics of Suicide," in Psychiatric Ethics, ed. Sidney Bloch and Paul Chodoff (Oxford: University Press, 1981), p.193.

8 See Sigmund Freud, Mourning and Melancholia, in The Standard Edition of the Complete Works of Sigmund Freud, ed. and trans. James Strachey (London: The Hogarth Press, 1915), 14, pp.250-252.

9 Richard Brandt, "The Morality and Rationality of Suicide," in A Handbook for the Study of Suicide, ed. Seymour Perlin (New York: Oxford University Press, 1975), p.72.

10 Stanley Hauerwas, "Rational Suicide and Reasons for Living," in Rights and Responsibilities in Modern Medicine: The Second Volume in a Series on Ethics, Humanism, and Medicine, ed. Marc Basson (New York: Alan R. Liss, $1 9 8 1 \longdiv { \text { , p.187. } }$ 
11 Joel Feinberg, Rights, Justice, and the Bounds of Liberty: Essays in Social Philosophy (Princeton, N.J.: Princeton University Press, 1980), p.122.

12 Hauerwas, "Rational Suicide and Reasons for Living," p.187. 13 Eric D'Arcy, Human
Moral Ects: $\frac{\text { An }}{\text { Evaluation (Oxford: Classay }} \frac{\text { Es }}{\text { Press, 1963), }} \frac{\text { Their }}{\text { p.81. }}$

14 Tom Beauchamp and James Childress, Principles of Biomedical Ethics, 2nd ed., (New York: Oxford University Press, 1983), p.99.

15 D'Arcy, Human Acts: An Essay in Their Moral Evaluation, p.91. 16 James Bogen, "Suicide and Virtue," in Suicide The Philosophical Issues, ed. M. Pabst Battin and David J. Mayo (New York: St. Martin's Press, 1980), p.287.

17 Ibid., pp. 289-290.

18 Stanley Hauerwas, Vision and Virtue: Essays in Christian Ethical Reflection (Notre Dame, Indiana: University of Notre Dame Press, 1974), p.74.

19 For example, see John Ladd, "Legalism and Medical Ethics," Journal of Medicine and Philosophy 4 (March 1979), pp.70-80. For a view of ethics and morality from a woman's perspective, see Carol Gilligan, In a Different Voice (Cambridge, Mass.: Harvard University Press, 1982).

20 Ladd, "Legalism and Medical Ethics," p.77.

21 A.I. Melden, Rights and Right Control (Oxford: Basil Blackwell, 1959), p.1.

22 Ibid., p.44.

23 Beauchamp and Childress, Principles of Biomedical Ethics, p.268.

24 Alisdair MacIntyre, After Virtue: A Study in Moral Theory (Notre Dame, Indiana: Notre Dame- University Press, 1981).

25 John Rawls, A Theory of Justice (Cambridge: Harvard University Press, 1971), especially sections 68 and 78. 
26 Beauchamp and Childress, Principles of Biomedical Ethics, pp.263-264.

27 For a useful discussion of major moral principles see Beauchamp and Childress, Principles of Biomedical Ethics.

28 Stanley Hauerwas, Truthfulness and Tragedy: Further Investigations into Christian Ethics (Notre Dame, Indiana: University of Notre Dame Press, 1977), p. 112 . $11,1138 \mathrm{~A}$.

29 Aristotle, Nichomachean Ethics Book V, chapter

30 St. Thomas Aquinas, Summa Theologiae, 2A2ae64.5

31 David Hume, "On Suicide," in The Philosophical Works of David Hume, 4 vols. (Boston: Little, Brown and Company, 1854), p.544.

32 Ibid., p. 545 .

33 Hauerwas, Truthfulness and Tragedy, pp.110-111.

34 Glanville Williams, "Euthanasia," Medico-Legal Journal 41 (1973), p.26.

35 Tom Beauchamp, "Suicide," in Matters of Life and Death, ed. Tom Regan (New York: Random House, 1980),

36 James F. Childress, Who Should Decide? Paternalism in Health Care (New York: Oxford University Press, 1982), p.56.

37 Karen Lebacqz and H. Tristam Engelhardt Jr., "Suicide," in Death, Dying, and Euthanasia, ed. Denis $\mathrm{J}$ Horan and David Mall (Washington D.C.: University Publications of America,1977), p.689.

38 Joel Feinberg, Rights, Justice, and the Bounds of Liberty, p. 247 .

39 I prefer to use "human worth" in lieu of "sanctity of life," because the latter implies a holiness or sacredness often grounded in a religious system of beliefs. "Human worth" is intended to include a wider range of meanings including secular conceptions of the value of human life. 
40 Aquinas, Summa Theologiae, $2 \mathrm{a} 2 \mathrm{ae} 64.5$.

41 Immanuel Kant, The Moral Law: Kant's Groundwork of the Metaphysic of Morals, trans. H. J. Paton (London: Hutchinson University Library, 1965), p.89.

42 Immanuel Kant, Lectures on Ethics, trans. Louis Infield (London: Methuen and Co., 1930), p.i54.

43 Aquinas, Summa Theologiae, 2a2ae 64.5 .

44 Eike-Henner W. Kluge, The Practice of Death (New Haven: Yale University Press, $\frac{1975), \text { p.125. }}{19}$

45 Ibid., p. 125.

46 Hauerwas, Truthfulness and Tragedy, p.108.

47 Mary Rose Barrington, "Apologia for Suicide," in Euthanasia and the Right to Death, ed. A.B. Downing (London: Peter Owen, 1969), p. 170 .

48 Hume, "On Suicide," p.541.

49 This is the fifth commandment for Catholics. It is the sixth commandment according to the Protestant tradition.

50 St. Augustine, The City of God, trans. Marcus Dods, D.D. (New York: The Modern Library, 1950), p.26.

51 Ibid., p. 22.

52 See, for example, Joseph Fletcher, Morals and Medicine (Boston: Beacon Press, 1954), p.195.

53 In the 01d Testament, see Samson (Judges 16:30); Saul and his armor-bearer (I Samuel 31:4); Ahi Thopel (II Samuel 17:23; Zimri (I Kings 16:18); Ptolemy Macron (II Maccabees 10:13); and Razis (II Maccabees 14:41). In the New Testament, see Judas (Matthew 27:5) and the attempted suicide of Paul's jailer (Acts 16:28).

54 Augustine, The City of God, p.27.

55 Antony Flew, "The Principle of Euthanasia," in Euthanasia and the Right to Death, p.44.

56 Joseph Fletcher, "Ethics and Euthanasia," in Ethical Issues in Death and Dying, ed. Robert F. Weir (New York: Columbia University Press, 1977), p.357. 
57 Joel Feinberg, Rights, Justice, and the Bounds of Liberty, p. 249 .

58 Joel Feinberg, Social Philosophy (Englewood Cliffs, New Jersey: Prentice-Hal1, $\frac{\text { Philosophy }}{1973), \text { p.59. }}$

59 Brandt, "The Morality and Rationality of Suicide," p.73. 
CHAPTER III: Suicide Intervention:

A Study in Paternalism

\begin{abstract}
From a psychiatric point of view, the question as to whether a person has the right to cope with the pain in his world by killing himself can be answered without hesitation. He does have that right.... The problem we struggle with is not whether the individual has the right to suicide; rather we face a twofold dilemma stemming from the fact that he does have it. Firstly, what is the extent to which the exercise of that right should be subject to limitations? Secondly, when the right is exercised, how can we eliminate the social stigma now attached to it? 1
\end{abstract}

This chapter will focus on the first of these two questions. To say that one has a right to suicide does not provide the answers to all the significant moral questions raised by suicide. For "to grant that persons have a right to suicide is not to say that they may kill themselves whenever they wish; one can advocate a rights-based analysis of suicide and yet hold that this right, unlike most other rights, is one which is almost always overridden." A rights-based analysis compels one to consider the correlative duties created by a right. Since the right to suicide is a negative right, it requires that others not interfere with the exercise of that right. There is a duty to refrain from intervention. However, when we look at society's reaction to a person's intervention in an attempted suicide, we can observe that not only is that action not morally 
censured, it is often hailed as a heroic deed. Is there an inconsistency between how we ought to act and how we do act vis-à-vis one's right to suicide, or is there something else at work in suicide intervention which can account for this phenomenon? Is suicide intervention ever justified?

The bystander, i.e., the individual who is confronted by a suicide attempt, is caught on the horns of a moral dilemma. On the one hand, he has a duty to refrain from interfering with the exercise of another's right to suicide. On the other hand, he has a duty to protect and promote the lives and interests of others. The first of these duties is grounded in the principle of respect for persons. It will be remembered that respect for persons "as free moral agents should entail that they be allowed to choose that which endows their lives with meaning as long as such a choice will not seriously affect the freedom of others or violate prior agreements between persons." 3

The duty to protect and promote the lives and interests of others is generated by the principle of beneficence. In its most minimal sense, the duty of beneficence requires that one prevent harm or evil. When does beneficence become a duty? It can be said that bystander $A$ has a duty of beneficence to do act $X$ for person $B$ if the following conditions are met: 
(1) B must be in danger of suffering $Y$ (a significant loss of or damage to, life or limb or liberty or happiness or good name or health or employment

(2) A's material possessions).

A's doing $X$ must be necessary to

(3) pront There must be a real possibility

(4) The likely harms to A are minimal.4

The bystander may, therefore, have a duty to intervene in a particular situation in which a significant harm is imminent. When this harm is the loss of life, intervention can be justified not only according to the principle of beneficence, but also according to the principle of human worth. How is the bystander to reconcile his duty to respect the choices of free moral agents with his duty to prevent harm?

As was observed in the last chapter, one attempt to solve this dilemma has been to deny that a free and autonomous agent could choose suicide. Those who advocate the medical model of suicide warn that "we must beware of viewing suicidal acts as rational undertakings based on clear intentions." 5 They claim that suicide is only attempted by those who are mentally ill and suffering from severe depressions, fear, anger, or frustration. Those who attempt suicide, according to the medical model, really do not desire to die, but only wish to react to the pain which they are experiencing. Suicide is seen not as an autonomous choice but as a 
cry for help. The medical model criticizes those who argue for a negative right to self-determination but, for those who are attempting suicide out of a feeling of loneliness or despair, that respect could easily be construed as further evidence of a lack or absence of care.

The medical model of suicide holds that suicide intervention is justified regardless of the wishes of the individual attempting suicide because intervention protects that individual from grave harm. Intervention, in this context, is paternalistic. Paternalism is defined as a "refusal to acquiesce in a person's wishes, choices, or actions for that person's own benefit."6 Paternalistic behavior has become more pervasive in medical care, particularly in dealing with suicide. This pervasiveness can be attributed to what H.L.A. Hart has described as a "general decline in the belief that individuals know their own interest best, and to an increased awareness of a great range of factors which diminish the significance attached to an apparently free choice...

There appears to be evidence to support the claim that one's capacity to make free choices in connection with suicide is often limited. Studies have shown that the "attempters most likely to complete suicide are usually older, male, divorced, widowed or single, abusers 
of alcohol or drugs, and

alcohol or drugs, and physically or mentally ill."8 If there is a common denominator in all these groups, it is the struggle with and for autonomy. Excluding for the moment the drug abusers and the ill, the need to live and choose autonomously seems to be assumed or thrust upon the remaining groups. It would be inappropriate then, not to intervene in the attempted suicide of a person who's ability to act autonomously is questionable and to base that nonintervention on a respect for that person's autonomy.

Intervention in the attempted suicide of an individual who may not really wish to die is, however, a practice that would be advocated by those who support a right to suicide grounded in the principle of respect for persons. Childress argues that

\begin{abstract}
if respect for persons is taken seriously as a principle, it does not imply that interventions in attempted suicides are never morally justified. It simply sets a limit on those interventions. Suicide prevention and intervention are important not only because of the principle of beneficence but also because of the principle of respect for persons. 9
\end{abstract}

To interpret the principle of respect for persons to mean that all interventions are morally unjustifiable is to miss half of its import. The principle of respect for persons demands that the free and autonomous choices of agents be respected as long as they do not seriously 
violate the rights of others. The principle of respect for persons does not, however, conflict with the principle of beneficence in establishing a duty to protect the welfare of those who are unable to act autonomously. Advocates of a right to suicide recognize that paternalistic intervention is justified when:

(1). The agent's capacity to act freely and deliberate rationally suffers from defects, encumbrances, and

(2) There is the probability that the agent will be harmed without intervention.

(3) The probable benefit of intervention outweighs the probable harm of non-

(4) The probable net benefit of the proposed intervention should also outweigh the probable net benefit of alternative interventions as well as nonintervention. 10

The question then becomes not whether or not there ought to be suicide intervention but, under what conditions is intervention justified? To recognize a right to suicide is not, as Hauerwas says, to affirm a "society that no longer wishes to provide the conditions for the miracle of trust and community."11 Both the principle of beneficence and the principle of respect for persons act as moral safeguards against the abandonment of a sense of moral responsibility on the part of a society for its members.

The medical model is praiseworthy for its concern 
for the welfare of all those who attempt suicide. This model, however, oversimplifies the problem of suicide. While it may be true that many who attempt suicide are incompetent, it is not the case that all who attempt suicide are incompetent. One cannot be assumed to be incompetent just because she wishes to end her own 1 ife. The weakness of the medical model is that it does not allow for the possibility of suicide being a rational and autonomous choice. Thomas Szasz, a critic of the medical model, claims that it would, in effect, respond to Patrick Henry's plea to "Give me liberty, or give me death" by saying "Give him commitment, give him electroshock, give him lobotomy, give him life-long slavery, but do not let him choose death."12

The virtue of the anti-intervention position is that it emphasizes the fact that suicide can be a rational and justified choice. This position requires that one's autonomous decision to suicide be respected because it is just that--an autonomous decision. The anti-intervention position, however, is guilty of perverting the principle of respect for persons. The danger in this position is that it does not recognize instances in which paternalistic intervention is justified.

The right to suicide that was defended in the last chapter is one that would fit comfortably with a policy of 1 imited and soft paternalism. 
Limited...p paternalism overrides a person's wishes, choices, and actions for that person's own good because he or she suffers from some defect, encumbrance, or limitation in decisionmaking or acting.... If the values used in the assessment of harms and benefits belong to the patient (i.e., the person acted upon even though he or she may not be a patient in the medical sense), the paternalism is soft (first emphasis added).13

To override a person's choice by appealing to his own values in cases in which he is incompetent to make decisions of his own would appear to be justifiable. On the other end of the spectrum, it would be almost impossible to justify overriding a person's choice when the paternalism appeals to values that are alien to the person, especially when that person is competent to make choices for himself.

In the case of suicide, it would be very difficult to justify intervention when the person attempting suicide is competent. If the person attempting suicide was suffering from some "defect, encumbrance, or limitation in decision-making," then intervention may indeed be justified.

What type of suicide intervention policy would be morally justifiable? It should be noted that suicide intervention may take many forms, including "prophylactic counseling, persuasion, or restraint prior to an attempt, immediate intervention in an attempt once it has begun, or resuscitation after an attempt has been made."14 
Even anti-paternalists have found some of these forms of intervention to be acceptable. John Stuart Mill, for example, argues that "advice, instruction, and persuasion" are acceptable means "by which society can justifiably express its dislike or disapprobation"15 for a particular conduct. Where Mill's position differs from others is in its claim that these are the only means of intervention that are justifiable.

One form of intervention that has proven to be ineffectual and cruel is making suicide a crime. As Norman St John-Stevas contends, "Whether it is hoped to reduce the suicide rate by changing the social structure or providing psychiatric help to potential suicides, the criminal law can do nothing to help."16 In fact, incarceration in either a jail or institution may even increase the likelihood of another suicide attempt, especially if the suicide was originally attempted because of a lack of autonomy or meaningful interaction. This type of suicide is what Durkheim has described as egoistic suicide. ${ }^{17}$ Fortunately, suicide is no longer considered to be a criminal act in most jurisdictions.

The principles of respect for persons, beneficence, and utility seem to dictate that "the least restrictive, humiliating, and insulting alternative should be employed."18 The less restrictive the means of 
intervention are, the more likely the intervention will be viewed as an expression of care. If many suicides are really cries for help, as some have argued, then this type of intervention may not only be effective in preventing the actual suicide but also in removing the feelings that motivated the attempt in the first place.

We are still faced with the problem of operationally defining what the least restrictive form of intervention is. Given that one has a prima facie right to suicide, suicide intervention should be designed to determine who is capable of competently exercising that right and who is not. This is easier said than done. As Robert Drinan asks, "Who can distinguish in would-be suicides the calm Stoic from the irrational exhibitionist?"19 This task may be difficult, but it is possible. It is incumbent on those who would support intervention to recognize that it is possible to determine whether or not an individual is competent without construing the desire to attempt suicide as a sign of incompetency.

Case 3-1: Dax Cowart, a 25 year old former Air Force pilot, was severly burned in a propane gas explosion that also killed his father. From the very beginning and throughout the 14 months of his treatment, Cowart requested that the treatment be discontinued. He was in agonizing pain and did not wish to live a life of dependency or a life in which he 
could not enjoy the same activities he had previously enjoyed. He expressed a desire to be allowed to go home and die. Cowart said, "I didn't intend to die from infection, but intended to commit suicide." Treatment was never discontinued despite his requests. 20

Robert Burt has argued that the refusal to terminate treatment on the part of the hospital was justified. Speaking about the principle of respect for person, Burt claims,

Because this principle mandates respect for each person's individual self-determination, careful attention must be given to the individual who claims its application. If we ignored the emotional context in which (Cowart) invoked this principle, we would find ourselves purporting to obey the wishes of a caricature, a cardboard cutout, rather than a fully fleshed and recognizable human being. 21

Intervention in this case appears to be justified, because of the uncertainty about the competence, voluntariness, and rationality of the patient coupled with the certainty about the irreversibility of suicide. When in doubt, one ought to err on the side of life. As Glanville Williams argues,

Theoretically...the law should allow some right of interposition to prevent a suicide. Self-destruction is frequently the outcome not of the settled philosophical determination of a balanced mind but of a passing impulse or temporary depression. 22

Given the emotional and volatile context in which most suicides occur, intervention and restraint seem 
reasonable, if not required. Perhaps no group of people has more contact with individuals who have attempted or who are contemplating suicide than health care professionals and, in particular, psychiatrists and those who work in the emergency room. What are the duties and responsibilities of these two groups of health care professionals? One difficult case in this regard is the professional in the emergency room who is faced with a person who has attempted suicide and who presently refuses to consent to any intervention. The dilemma for this health care professional is in resolving the duty to preserve life and the duty to respect the wishes of the patient. However, in such circumstances, it is often impossible to have any knowledge of a person's competence or real intentions. According to Childress, it is because of this lack of knowledge and the need to act swiftly that "treatment should be immediate and vigorous, even if the person refuses treatment... Both care and respect demand treatment in such cases." 23

Psychiatrists are confronted with at least two difficult problems in dealing with a person who is contemplating suicide. First, they need to determine the competency of the person. Is the person contemplating suicide making a rational decision "based on a realistic assessment of his life situation?"24 It often takes time to determine the competency and real intentions 
of a person. It is for this reason that a "policy of postponement" is often advocated by psychiatrists. According to Heyd and Bloch,

we are justified in asking or even forcing potential suicides to consider their attitude, to give themselves a second chance, or to defer a final decision lest there be a change in circumstances. The postponement policy is logically sounder than nonintervention because the intervention itself is a reversible

It may be the case that a person's decision may change simply by waiting, but it is not clear that the use of force in making a person wait is justified in all circumstances. Also, a limit needs to be placed on the time period that a person is expected to wait. As was noted in chapter II, things may get better, but things may get worse. If a person is found to be competent, it may be appropriate to suggest that he wait and see if his decision changes over time but, it seems that intervention beyond that point is unjustified. In the case of Dax Cowart, although a psychiatrist eventually concluded that Cowart "could not be considered mentally $i l l, " 26$ his requests were still overridden. The paternalistic intervention that preceded the psychiatrist's determination appears to have been morally justified but, after this determination was made, the intervention and restraint ought to have been discontinued. Williams argues, 
Nothing longer than a temporary restraint could be defended. I would gravely doubt whether a suicide attempt should be a factor leading to a diagnosis of psychosis or to compulsory admission to a hospital. Psychiatrists are too ready to assume that an attempt sick person. 27 commite is the act of a mentally

A second problem that psychiatrists and other health care professionals face is determining their duty to the competent person who is going to attempt suicide. Some have argued that health care professionals have a moral duty to assist those who have made a rational decision to end their own life. The law and the AMA, however, have found assisting suicide to be an unacceptable practice. Health care professionals may then find themselves in a position where what they believe to be their moral duty comes into conflict with their legal and professional duty. This is an extremely difficult dilemma to resolve. It may be up to the individual's conscience to decide what he or she ought to do in a particular case, but there appear to be some strong arguments in favor of prohibiting health care professionals from engaging in the practice of assisting suicides. As was noted in the previous chapter, it may be appropriate to refrain from making assisted suicide a legal right and a medical practice because of the potential for abuse, even though it might be justified in some circumstances. According to Beauchamp and 
Childress,

It may be necessary to prohibit by rule and policy some acts that do not appear to be wrong in some circumstances in order to maintain a viable practice that, for the most part, expresses our principles and avoids seriously undesirable consequences. 28

Another argument against health care professionals assisting suicide has to do with the trust that exists between society and the medical profession. The medical community is committed to the preservation and the quality of life. While the practice of allowing patients to die is authorized in some cases, killing or assisting in a killing is found to be unacceptable in all cases. It is the health care professional's commitment to this rule that forms the "basis of trust between patients and health care professionals."29 Although the practice of assisting a competent person's suicide can be said to involve a health care professional only minimally and often in what appears to be a justified act, it would involve such a fundamental shift in the relationship between society and the medical profession that the burden of proof rests on those who would advocate such a change in present policy or practice.

To conclude, a policy of limited and soft paternalism appears to be the only morally defensible policy of suicide intervention. In theory, suicide intervention is prima facie wrong because it violates one's right 
to self-determination. In practice, however, suicide intervention is justifiable and, in some circumstances, even obligatory because many people who attempt suicide are not competent and because nonintervention is irreversible. But only a temporary intervention is justified in order to determine the competency of the person attempting suicide. Those who advocate continued intervention after the person has been found to be competent are required to provide justification.

Notes

1 Jerome Motto, "The Right to Suicide: A Psychiatrist's View," in Suicide: The Philosophical Issues, ed. M. Pabst Battin and David T. Mayo (New York: St. Martin's Press, 1980), p.213.

2 M. Pabst Battin, Ethical Issues in Suicide (Englewood Cliffs, New Jersey: Prentice-Ha $\frac{11}{1982), ~ p .178 . ~}$

3 Karen Lebacqz and H. Tristam Engelhardt, "Suicide," in Death, Dying, and Euthanasia, ed. J. Hor an and David Mal (Washington, D.C.: University Publications of America, 1977), p.689.

4 These first three conditions are taken from Eric

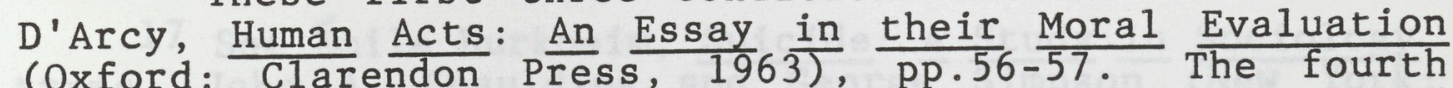
(Oxford: Clarendon Press, 1963), pp.56-57. The fourth
condition is added by James Childress in who Should Decide? Paternalism in Health Care (New York: Oxford University Press, 1982 ), p.31. This additional requirement would protect against making the sacrifice of one's life a duty if it would prevent the loss of more than one life.

5 Erwin Stengel, "A Matter of Communication," in On the Nature of Suicide, ed. Edwin Shneidman (San

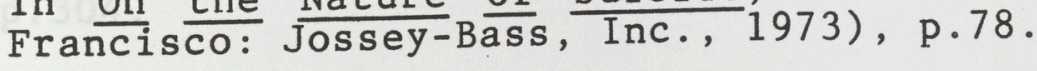


6 Childress, Who Should Decide? Paternalism in

7 H.L.A. Hart, Law, Liberty, and Morality (Stanford,

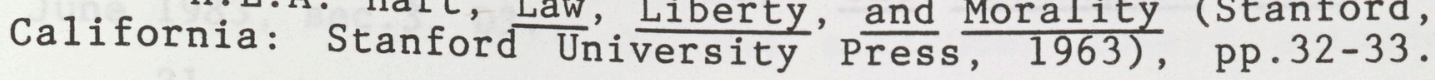

8 See David H. Smith and Seymour Perlin, "Suicide," in The Encyclopedia of Bioethics, ed. Warren T. Reich (New York: Macmillan and Free Press, 1978), p.1618. It is also interesting to note that Nevada, a state which is noted for placing a high premium on individual liberty and autonomy, has by far the highest suicide rate of any state.

9 Childress, Who Should Decide? Paternalism in Health Care, p.16i.

10 Ibid., Chapter V.

11 Stanley Hauerwas, Truthfulness and Tragedy: Further Investigations into Christian Ethics (Notre Dame: University of Notre Dame press, 1977), p.113.

12 Thomas Szasz, "The Ethics of Suicide," in Suicide: The Philosophical Issues, p.193.

13 Childress, Who Should Decide? Paternalism in Health Care, pp.17-18.

14 Battin, Ethical Issues in Suicide, p.154.

15 John Stuart MI11, On Liberty (New York: Henry Holt and Co., 1887), p.171.

16 Norman St. John-Stevens, Life, Death and the Law: Law and Christian Moral in England and the United States (Bloomington, Indiana: Indiana University Press, 1961), p.256. 17 See Émile Durkheim, Suicide: A Study
trans. John A. Spaulding and George Sociology, The Free Press, 1951).

18 Childress, Who Should Decide? Paternalism in Health Care, p.113.

19 Robert F. Drinan, "Should There Be a Legal Right to Die?" in Ethical Issues in Death and Dying, ed. Robert F. Weir (New York: Columbia University Press, 1977), p. 304 . 
20 This case is drawn from "A Happy Life Afterward Doesn't Make Up for Torture," The Washington Post, 26
June 1983, sec.3, D3.

21 Robert A. Burt, Taking Care of Strangers: The

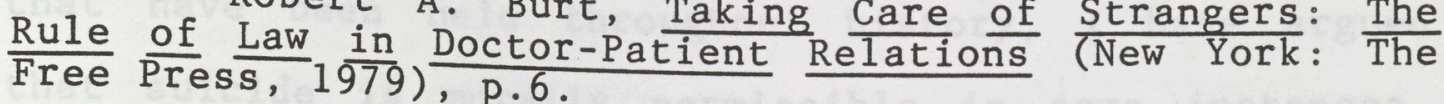

22 Glanville Williams, The Sanctity of Life and the Criminal Law (New York: Alfred A. Knopf, 1957),

23 Childress, Who Should Decide? Paternalism in Health Care, p.162.

24 Motto, "The Right to Suicide: A Psychiatrist's View," p.213.

25 David Heyd and Sidney Bloch, "The Ethics of Suicide," in Psychiatric Ethics, ed. Sidney Bloch and Paul Chodoff (Oxford: Oxford University Press, 1981), p. 201.

26 Burt, Taking Care of Strangers: The Rule of Law in Doctor-Patient Relations, p.3.

27 Glanville Williams, "Euthanasia," Medico-Legal Journal 41 (1973), p.27.

28 Tom Beauchamp and James Childress, Principles of Biomedical Ethics (New York: Oxford University Press, 1983), pp.119-120.

29 Ibid., p. 120. 
CONCLUSION: The Challenge of Suicide

Contrary to most of the attitudes toward suicide that have been held throughout history, I have argued that suicide is morally permissible in some instances. Suicide may even be morally justified in some cases, especially in light of the tragic dilemmas which have begun to result from some developments in biomedical technology. In addition, a rights-based analysis of the major moral principles involved in suicide would appear to support the claim for a prima facie right to suicide. This right is ultimately grounded in the principle of respect for persons. However, while a negative right to suicide would theoretically require a bystander not to interfere, a policy of limited suicide intervention can be morally justified by the principles of beneficence and respect for persons.

An ethical analysis is an important tool for understanding one's rights and duties in connection with suicide, but suicide is not just a problem for ethicists or philosophers. Suicide challenges man qua philosopher, man qua member of a community, man qua policy-maker, man qua bystander; in short, man qua man.

The medical community, for example, has generally regarded suicide as a challenge to its basic aim and purpose: to preserve life. In this sense, suicide is 
seen as a "medical heresy." Heyd and Bloch observe that

most medical and psychiatric problems are concerned with the adjustment of the right means to a given end that is basically shared by doctor and patient; suicide however focuses on the end itself, about which the two parties may hold polarly opposite views.... The question is not how to achieve a better, more fruitful life, but whether to live at all.1

Suicide challenges the medical community's perception of its own values and goals. Suicide forces the medical community to examine how its general aim to preserve life translates into a particular policy for preserving life and preventing death.

Suicide also presents society with a great challenge. It may be viewed as the ultimate test of a society's willingness to recognize the right of an individual to decide what is in his or her own best interest. Suicide can also be seen as a test of society's willingness to care for those who are troubled or abandoned. As Hauerwas makes clear throughout his writings, the claim that "nobody cares for a person" is not part of a justification for suicide but is, instead, a strong moral indictment of society. The challenge society faces is to try to balance its duty to respect the choices of its members with its duty to preserve and promote their lives and interests.

In order to be able to achieve this balance, more 
research needs to be conducted by those individuals who are working in medicine, psychology, and sociology, to determine the variables that are involved in a suicide. The circumstances that lead to suicide are often a good barometer of the needs that a society still must meet. If, for example, it can be shown that loneliness is an important factor leading to suicide, then the emphasis of suicide intervention should shift from hospitalization to outreach programs in which a sense of belonging can be fostered. Finally, suicide presents people with a tremendous personal challenge. This challenge is not so much to provide reasons for dying as it is to provide reasons for living. Suicide forces individuals to confront some difficult and weighty questions concerning the nature of the world, their place in it, what gives meaning to their life, and what role and effect suicide will have for them.

I live but do not have the power to live. And further, I may die at any moment but I am powerless to die. It was not in my power, nor in my parent's power, to elect my self into existence. Though they willed a child or consented to it they did not will me--This $I$, thus and so. And so also I now, though I will to be no more, cannot elect myself out of existence, if the inscrutable power by which I am, elects otherwise. Though I wish to be mortal, if the power that threw me into being in this mortal destructible body elects me into being again there is nothing I can do about that. I can destroy the life of my body. Can I destroy myself? 
This remains the haunting question of the biterature of suicide.... Men can practice commit biocide, not self-creation; they can self-destruct whether they can commit suicide, self-destruction, remains a question.

H. Richard Niebuhr, The Responsible Self

Suicide, therefore, challenges people to provide a raison d'être. Part of the reason that suicide is so disconcerting is probably due to the difficulty experienced in trying to formulate what would be considered an adequate raison d'être. Why do most people refrain from taking their own lives?

It is a decision that I shall not take, at least not yet, for the reason that I have got myself annuities from two sovereigns and I should be inconsolable if my death enriched two crown heads.

Voltaire, Lettres

It may be easier to list those reasons that do not lead most people to refrain from suicide. A list of these reasons would probably include the threat of criminal punishment, involuntary hospitalization, or even some philosophical argument. Why is it then that most people do not end their own lives?

Perhaps it is good taste that holds us back, or modesty, or pride--or merely a sense of humour, which isn't to be despised.... Or, of course, hope which (along with curiosity), whether or not it springs eternal, can last out our limited existences. Experience suggests that there is something in the folk wisdom that tells us, when one door closes, another opens. 2 
Notes

1 David Heyd and Sidney Bloch, "The Ethics of Suicide," in Psychiatric Ethics, ed. Sidney Bloch and Paul Chodoff (Oxford: Oxford University Press, 1981), p. 185 .

2 D.J. Enright, The Oxford Book of Death (Oxford: Oxford University Press, 1983), p. 84 


\section{BIBLIOGRAPHY}

"A Happy Life Afterward Doesn't Make Up for Torture." The Washington Post, 26 June 1983, sec.4, p.D3.

Alvarez, A. The Savage God: A Study of Suicide. New

Aristotle. The Basic Works of Aristotle. Edited by Richard McKeon. New York: Random House, 1941.

Augustine. The City of God. Translated by Marcus Dods, D.D. New York: The Modern Library, 1950.

Battin, M. Pabst. Ethical Issues in Suicide. Englewood Cliffs, N.J.: Prentice-Hal1, 1982 .

- and Mayo, David J., eds. Suicide: The Philosophical Issues. New York: St. Martin's Press, 1980 .

Beauchamp, Tom L. "Suicide." In Matters of Life and Death, pp:67-108. Edited by Tom Regan. New York:
Random House, 1980.

and Childress, James F. Principles of Biomedical Ethics. 2nd ed. New York: Oxford University Press, 1983 .

- and Perlin, Seymour. Ethical Issues in Death and Dying. Englewood Cliffs, N.J.: Prentice-Hall, $\overline{1978 .}$

Brandt, Richard. "The Morality and Rationality of Suicide." In A Handbook for the Study of Suicide,

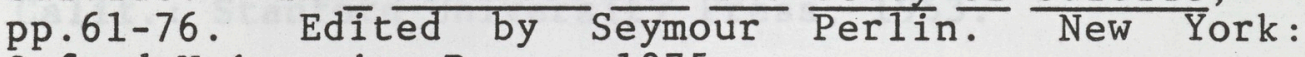
Oxford University Press, 1975.

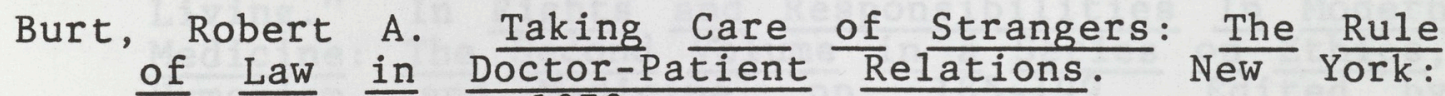
$\frac{\text { of }}{\text { The }} \frac{\text { Law }}{\text { Free }}$ in $\frac{\text { Doctor }-P}{\text { Press, } 1979 .}$

Childress, James F. Who Should Decide? Paternalism in Health Care. New York: Oxford University Press, $\overline{19} 8 \overline{2}$.

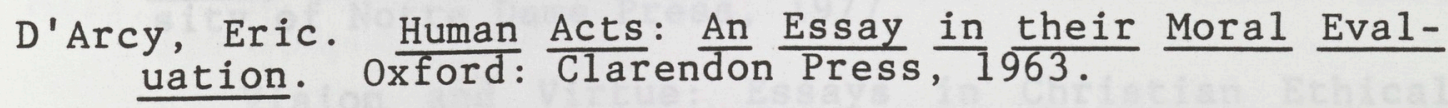

Daube, David. "The Linguistics of Suicide." Philosophy and Public Affairs 1 (Summer 1972): 387-437. 
Downing, A.B., ed. Euthanasia and the Right to Death: The $\frac{\text { Case }}{1969 .}$ for Voluntary Euthanasia. London: Peter

Durkheim, Émile. Suicide: A Study in Sociology. Trans-

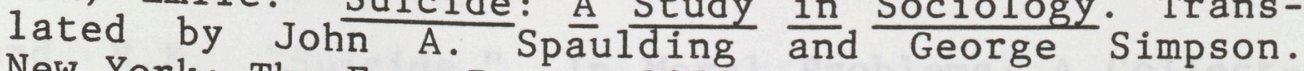
New York: The Free Press, 1951.

Enright, D.J. The Oxford Book of Death. Oxford: Oxford University Press, 1983. Feinberg, Joel. Rights, Justice, and the
Liberty: Essays in N.J.: Princeton University Press, 1980.

Social Philosophy. Englewood Cliffs, N.J.: Prentice-Ha11, 1973 .

Fletcher, Joseph. "In Defense of Suicide." In Suicide and Euthanasia: The Rights of Personhood, pp.38-50. Edited by Samuel E. Wallace and Albin Eser. Knoxville, Tennessee: The University of Tennessee Press, 1981 .

- Morals and Medicine. Boston: Beacon Press, 1954.

Freud, Sigmund. "Mourning and Melancholia." In The Standard Edition of the Complete Works of Sigmund Freud. Edited and translated by James Strachey. London: The Hogarth Press, 1915.

Gilligan, Carol. In a Different Voice. Cambridge, Mass.: Harvard University Press, 1982.

Hart, H.L.A. Law, Liberty and Morality. Stanford, Calif.: Stanford University Press, 1963.

Hauerwas, Stanley. "Rational Suicide and Reasons for Living." In Rights and Responsibilities In Modern Medicine: The Second Volume in a Series on Ethics, Humanism, and Medicine, pp. 185-199. Edited by Marc D. Basson. New York: Alan R. Liss, Inc., 1981 .

tions into Christian $\frac{\text { Truthfulness }}{\text { Ethics. }}$ and $\frac{\text { Tragedy }}{\text { Etre Dame: Univer- }}$ sity of Notre Dame Press, 1977.

Vision and Virtue: Essays in Christian Ethical Reflection. Notre Dame, Indiana: University of Notre Dame Press, 1974. 
Heyd, David and Bloch, Sidney. "The Ethics of Suicide." In Psychiatric Ethics, pp. 185-202. Edited by Sidney Bloch and Paul Chodoff. Oxford: Oxford University Press, 1981.

Holland, R.F. "Suicide." In Moral Problems: A Collection of Philosophical Essays, pp.345-359. $\frac{\text { Edited }}{\text { by }}$ by James Rachels. New York: Harper \& Row, 1971.

Hook, Sidney. "The Ethics of Suicide." In Beneficent Euthanasia, pp. 57-59. Edited by Marvin Kohl. Buffalo, New York: Prometheus Books, 1975.

Hume, David.
4 vols. Boston $\frac{\text { Philosophical }}{\text { Little, Brown and }} \frac{\text { Works }}{\text { Company, }} \frac{\text { David }}{1954}$.

Kant, Immanuel. Lectures on Ethics. Translated by Louis Infield. London: Methuen and Co., 1930.

- The Moral Law: Kant's Groundwork of the Metaphysics of Morals. Translated by H.J. Paton. London: Hutchison University Library, 1956.

Kluge, Eike-Henner $W$. The Practice of Death. New Haven, Conn.: Yale University Press, 1975.

Ladd, John. "Legalism and Medical Ethics." The Journal of Medicine and Philosophy 4 (March 1979):70-80.

Lebacqz, Karen and Engelhardt, H. Tristam. "Suicide." In Death, Dying, and Euthanasia, pp.669-705. Edited by J. Horan and David Mall. Washington, D.C.: University Publications of America, 1977.

MacIntyre, Alisdair. After Virtue: A Study in Moral Theory. Notre Dame: Notre Dame University Press, 1981.

Margolis, Joseph.
Columbus, Ohio: $\frac{\text { Negativities }}{\text { Charles E. Merrill }} \frac{\text { The }}{\text { Publishing }} \frac{\text { of }}{\text { Co. }}$, 1975.

Melden, A.I. Rights and Right Conduct. Oxford: Basil Blackwe11, 1956.

Mi11, John Stuart. On Liberty. New York: Henry Holt and Company, 1887 .

Plato. The Dialogues of Plato, 2 vols. Translated by

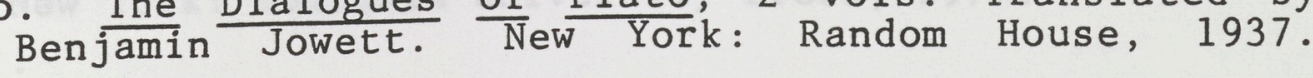


Rawls, John. Aniversity $\frac{\text { A }}{\text { Press, 1971. }}$ Uustice. Cambridge: Harvard Roman, Jo. Exit House New York: Seaview Books, 1980.

St. John-Stevas, Norman. Life, Death and the Law: Law and Christian Morals in England and the United States. Bloomington, Indiana: Indiana University Press, 1961 .

Seneca. Epistle 70 in Ad Lucilium Epistulae Morales, 3 vols. Translated by $\frac{\text { Lichard }}{\text { M. Gummere }}$. Cambridge, Mass.: Harvard University Press, 1950.

Shah, Diane K. and Gosnell, Mariana. "Rational Suicide?" Newsweek, 2 July 1979, p.87.

Smith, David H. and Perlin, Seymour. "Suicide." In The Encyclopedia of Bioethics, Volume IV, pp. 16181626 Edited by Warren T Reich. New York: Macmillan and Free Press, 1978.

Stengel, Erwin. "A Matter of Communication." In On The Nature of Suicide, pp.74-80. Edited by Edwin Shneidman San Francisco: Jossey-Bass, Inc., 1973.

"Suicide." In New Catholic Encyclopedia. Prepared by an editorial staff at Catholic University of America. Palatine, I11.: Jack Hearty and Assoc., Inc., 1981.

The Compact $\frac{\text { Edition }}{\text { New York }} \frac{\text { of }}{\text { Oxford }}$ University Press, $\frac{\text { Oxford }}{1971 .}$ English Dictionary.

Thomas Aquinas. Summa Theologiae. Translated by Marcus Lefebure, 0.P. New York: McGraw-Hill Publishers, 1964.

United States Department of Health and Human Services: Public Health Service; National Center for Health Statistics. Vital Statistics of the United States 1978: Volume II-Mortality, Tables 1-5, 1-6, $\frac{\text { 1-9. }}{\text { I }}$

Weber, Max. Max $\frac{\text { Weber }}{\text { on }}$ Law in Economy and $\frac{\text { Society. }}{\text { Edward }}$ Edited by Max Rheinstein. Translated by Edward
Shils and Max Rheinstein. Cambridge, Mass.:Harvard University Press, 1954.

Weir, Robert F., ed. Ethical Issues in Death and Dying. New York: Columbia University Press, 1977. 

Williams, Glanville. "Euthanasia." Medico-Legal Journal
$41(1973): 14-34$. York: She Sanctity of Life and the Criminal Law. New 
PX 000827343

HECKMAN

BINDERY INC 